pratama-syndicate

A B C D E

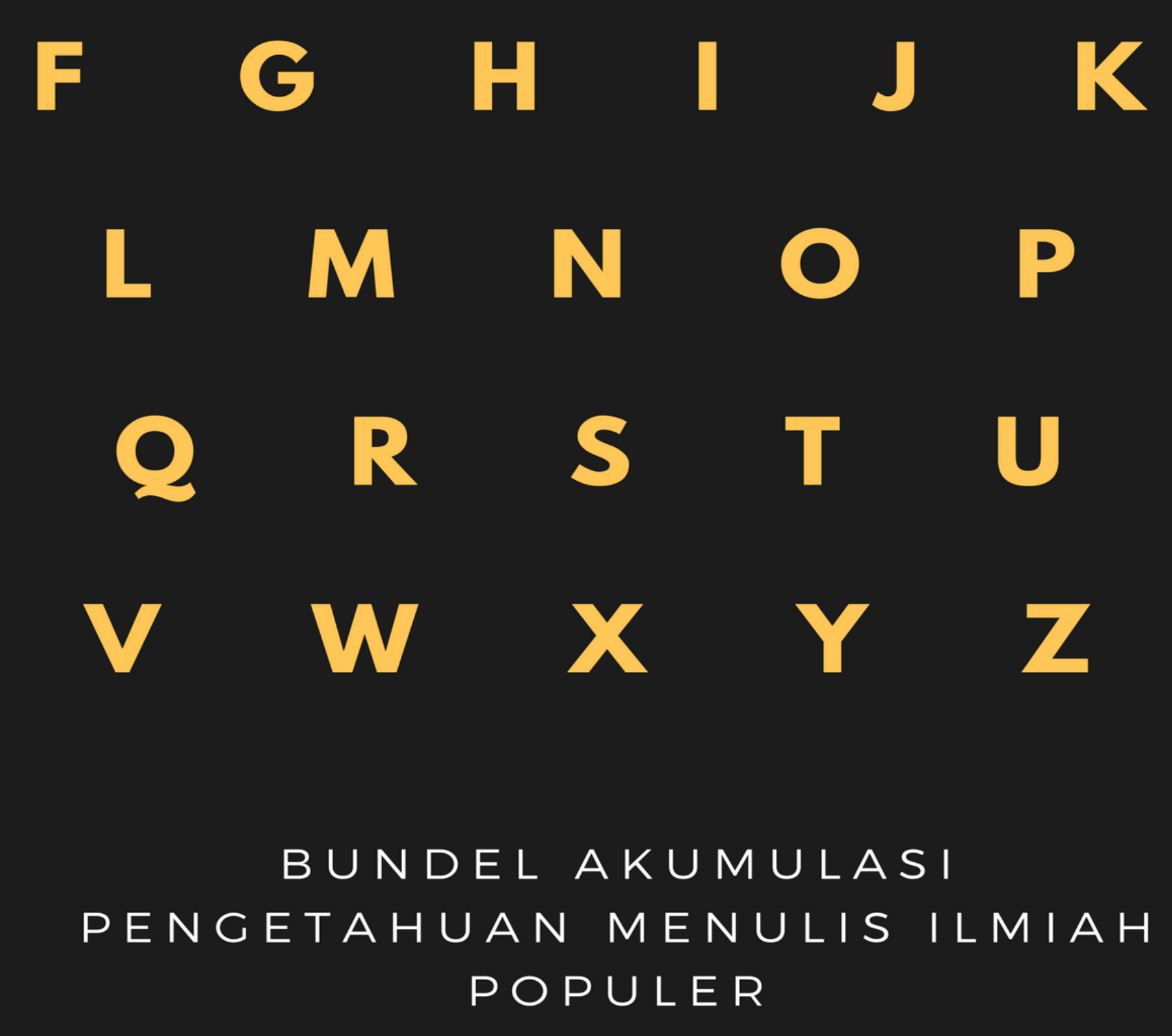

BERGERAK MENULIS!

M. RIZKI PRATAMA 


\section{Bergerak Menulis!}

\section{Akumulasi Pengetahuan Menulis Artikel Ilmiah Populer}

Bundel Edisi 1.0

Diterbitkan secara daring dan bebas biaya sebagai Project-One inisiatif Pratama-Syndicate

Kota Kediri-Jawa Timur-Indonesia

Project-One merupakan inisiasi penyebaran dan pembagian pengetahuan aksesibel di bidang ilmu sosial melalui berbagai media daring tanpa dibatasi oleh lisensi dan upah dengan tagline free-openknowledge

Kritik, Saran, Diskusi dan Konsultasi via e-mail rizkipratama90@gmail.com

Desain cover oleh @canva (www.canva.com)

(C) M. Rizki Pratama, 2017. Bergerak Menulis! Akumulasi Pengetahuan Menulis Artikel Ilmiah Populer. Pratama-Syndicate: Kediri. Harap Mengutip Jika Menggunakan Sebagai Sumber. Kontak: Rizkipratama90@gmail.com 


\section{Pengantar Penulis}

"Menulis adalah bekerja untuk keabadian" sastrawan klasik Pram lugas menuliskan, lalu untuk kita sebagai golongan terdidik tentu menulis adalah sebuah kewajiban, suka tidak suka dan mau tidak mau. Tak hanya pandai berdebat tapi juga rajin menulis, terbukti para cendikiawan pun sangat intens menelurkan berbagai ide-ide progresif dan kritis melalui tulisan. Sebuah ketidakmungkinan ketika golongan terdidik hanya menyuarakan pendapat secara verbal. Semua pasti menulis untuk perjuangan. Menulis tidak hanya untuk diri sendiri tapi juga untuk orang lain. Terutama memberi manfaat bagi kehidupan dengan inspirasi dan sumbangan pemikiran untuk kebangsaan

Keseluruhan tulisan ini bukanlah sebuah buku (karena memang tidak layak disebut buku) namun lebih tepatnya sebuah bundel catatan. Lengkapnya sebuah bundel kumpulan catatan tulisan tentang penulisan sebuah artikel populer. Bundel ini hadir sesuai dengan catatan penulis ketika menulis dan berusaha memperbaiki tulisan secara kontinyu. Jadi bundel ini merupakan hasil belajar penulis sendiri, yang tentu bukanlah sebuah tulisan yang hendak menghakimi tulisan kita sendiri dan beralih mengikuti tips-tips tertentu ala tulisan motivasi. Akan tetapi bundel ini hanya memberikan perspektif pembelajaran bersama, saling memberikan pengetahuan baru, saling memberikan pengkayaan di dunia penulisan, dan tentu saling menghargai keputusan seorang penulis yang terbukti dalam setiap tulisan masing-masing pribadi. 
Bundel ini ditulis untuk memberikan jalan pengkayaan pengetahuan menulis bagi siapa saja yang mau belajar bersama, tak hanya golongan terdidik saja, terutama untuk dapat mengeluarkan ideide segar dalam tulisan ilmiah populer ilmu sosial. Disamping itu bundel ini juga muncul atas keprihatinan minat baca yang rendah disertai juga minat menulis yang rendah. Diharapkan adanya tekanan untuk menulis akan membuat minat baca juga akan meningkat. Membaca harus menulis, dan menulis harus membaca. Sedikitnya bundel ini mencoba untuk menghadirkan hal-hal dasar dalam penulisan yang dapat dipelajari bersama untuk mengembangkan tulisan-tulisan yang lebih bermutu dan progresif di kemudian hari.

Munculnya berbagai kanal online sebagai media untuk menulis seharusnya memacu berbagai kalangan untuk mulai menelurkan tulisan bermutu. Kritik harus menjadi budaya dengan disertai keterbukaan antara kedua belah pihak, baik subjek kritik ataupun objek kritik sehingga mampu membangun narasi logika sehat dalam kehidupan bangsa. Kanal kompasiana, geotimes, selasar, opini id, kumparan dan lain lain harus mampu membuat perubahan pola pikir masyarakat baik sebagai produsen tulisan sekaligus penikmat untuk mendapatkan refleksi sehat atas sebuah persoalan penting.

Bundel ini mencoba menuliskan secara komprehensif berbagai pengetahuan dalam dunia tulis menulis terutama bagi para pemula (seperti penulis sendiri). Jadi bundel ini bukan sebuah tulisan tentang penjelasan teoritik untuk menulis sebuah artikel akan tetapi lebih kepada hal-hal sederhana apa saja yang harus dikuasai oleh penulis sebagai dasar untuk menelurkan sebuah tulisan, sehingga bukan merupakan panduan advance akan tetapi lebih kepada para pemula 
alias beginner. Semoga bundel ini dapat memberikan pengetahuan bersama untuk menulis demi kemajuan bangsa.

Kediri, 28 Agustus 2017

M. Rizki Pratama

iv|B ergerak M e nulis! 


\section{Biodata Penulis}

\section{Rizki Pratama}

Alumnus Fakultas Ilmu Sosial dan Ilmu Politik Universitas Airlangga (2009-2013), dan Fakultas Ilmu Sosial dan Ilmu Politik Universitas Gadjah Mada (2014-2016). Seorang Pemula dalam dunia tulis-menulis. Rekam jejak tulisan dapat dilihat di www.pratamarizkim.wordpress.com ataupun via mesin pencari google. Terbuka untuk kritik, saran, diskusi ataupun konsultasi silahkan kontak via e-mail rizkipratama90@gmail.com, twitter @pratamarizkim, facebook/pratamarizkim 


\section{Daftar Isi}

Pengantar Penulis ......................................................................................... ii

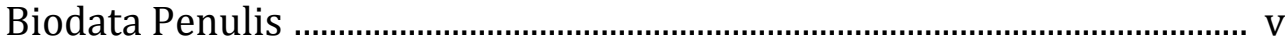

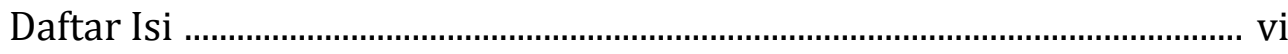

Bab I Fundamental Penulisan Artikel ........................................................... 1

Bab II Inisiasi Penulisan Artikel ................................................................. 14

Bab III Aksi Penulisan Artikel ................................................................... 38

Bab IV Evaluasi Penulisan Artikel ............................................................... 62

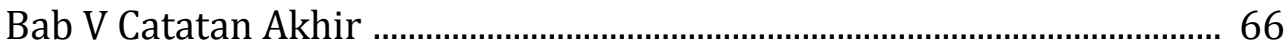

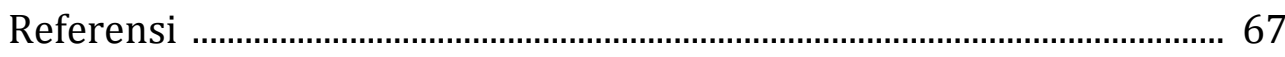

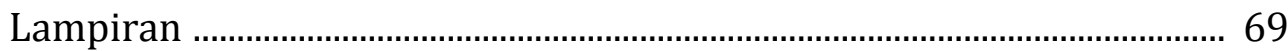

vi|B ergerak Menulis! 


\section{BAB I}

\section{FUNDAMENTAL PENULISAN ARTIKEL}

Bagian ini merupakan dasar-dasar utama dalam penulisan sebuah artikel ilmiah populer lengkapnya memberikan dasar-dasar abstrak yang paling penting sebelum memulai menulis. Seperti logika dasar yang paling penting untuk dikuasai dan hal-hal mendasar lainnya. Penulis memberikan enam konsep penting yang harus dikuasai seorang penulis sebelum bergerak ke penulisan teks artikel yang sebenarnya.

\section{Kepentingan Penulisan}

Setiap manusia memiliki kepentingan dalam hidupnya, seperti apa yang menjadi tujuan hidup dan apa yang diperjuangkan untuk mencapai sesuatu. Dalam hal apapun dipastikan ada unsur kepentingan, realita sehari-hari dapat membuktikannya. Misalnya anda memilihmilih teman agar sesuai dengan kepentingan anda, bahkan kadangkala memilih teman yang hanya menguntungkan anda. Hal tersebut sama dengan tulisan yang akan anda ceritakan kepada orang lain, apa maksud anda dengan tulisan tersebut. Apakah anda hanya ingin dianggap pintar? Bermaksud menjernihkan masalah? Atau yang lain. Dalam penulisan tentu ada yang hendak anda sampaikan dan hendak anda capai seperti menulis opini koran agar pendapat anda dapat dibaca orang lain dan mungkin menjadi populer. Banyak penulis memperjuangkan ide agar menjadi kenyataan baik melalui kritik kepada pemerintah ataupun membakar semangat para aktivis. Bahkan dengan alasan yang paling praktis bagi mereka yang tertarik dengan pendapatan sebagai penulis 
Mungkin dua hal pasti yang dapat menjadi kepentingan anda dalam sebuah tulisan yaitu pertama kepentingan idealis dan yang kedua kepentingan pragmatis. Sebaik-baiknya kaum intelektual seharusnya kepentingan penulisan kita atau anda harus idealis, anda harus memperjuangkan sesuatu lewat tulisan anda.

Dalam kepentingan ini juga harus memperlihatkan konsistensi dan kepakaran tulisan. Dalam hal ini yang dimaksud konsistensi adalah bahwa kita sebagai penulis harus konsisten atau ajeg dalam berpendapat jangan seperti hari ini menulis mendukung $\mathrm{x}$ akan tetapi dengan cepat berubah membantai $\mathrm{x}$ dan mendukung $\mathrm{y}$. Selain itu kepakaran berarti kita harus menulis sesuai dengan apa yang kita ketahui dan tidak berpindah-pindah topik. Misalkan anda tertarik pada tema kepemudaan maka teruslah menulis dengan berbagai topik tentang itu. Jangan berganti-ganti topik seperti kita adalah orang yang paling tahu segalanya.

Silahkan anda searching via google para penulis artikel yang sangat idealis dengan tujuannya, konsisten dan pakar dalam bidangnya misalnya ada Emerson Yuntho seorang aktivis anti korupsi yang gemar menulis dengan topik anti korupsi, Zainal Mochtar juga menulis dengan topik demikian, ataupun ada Ahmad Baedowi tentang kritik pendidikan di Indonesia, Prof. Miftah Thoha tentang manajemen ASN, Prof. Rhenald Khasali tentang konsep disruspi, seorang Ekonom Toni Prasetiantono, analis politik Burhanuddin Muhtadi, ilmuwan sosial lain seperti Novri Susan yang tentang konflik ataupun Airlangga Pribadi tentang keadilan dan demokrasi. Kita semua dapat belajar konsistensi dan kepakaran dari mereka hanya dengan membaca tulisan mereka. 


\section{Kebiasaan Observasi}

Apa yang anda tulis sebenarnya merupakan apa yang anda pernah alami (baik kenyataan atau dalam alam pikiran) melalui panca indera anda. Dari mata anda melihat banyak anak jalanan di sekitar lampu lintas, dari tangan anda merasakan ketika bersalaman dengan mereka bahwa tangan mereka kotor dan kasar, dari telinga anda ternyata anda mendengar bahwa mereka sering mengeluarkan kata-kata kotor, kemudian otak anda merefleksikan bahwa semua itu adalah salah pemerintah. Tentu tidak semua berpendapat demikian, setiap orang mempunyai observasi yang berbeda-beda seperti membaca buku, mengikuti diskusi, melihat film ataupun yang lain. Bahkan ada yang membaca berita tanpa verifikasi yang kemudian langsung percaya bahwa itu nyata dan menyebarkannya via media sosial. Tentu mempercayai berita heboh tanpa verifikasi bukanlah yang hendak kita gunakan sebagai hasil observasi kita.

Saran sebagai penulis adalah kita harus dapat merefleksikan hasil observasi kita. Dua hal penting dalam refleksi adalah pertama refleksi secara makro dimana hasil observasi kita pada apa yang kita dapatkan dari pengalaman panca indera anda arahkan ke sesuatu yang lebih luas dan umum seperti sekumpulan pengemis di lampu merah yang anda refleksikan sebagai kegagalan pemerintah dalam melindungi tumpah darahnya. Kedua adalah refleksi secara mikro, anda dapat merefleksikan sekumpulan pengemis tersebut sebagai pengalaman kegagalan hidup seseorang ataupun naik-turunnya kehidupan individu. Dua hal tersebut juga dapat membawa kita dalam nuansa tulisan yang berbeda-beda yaitu menulis dengan topik-topik umum atau topik-topik yang sangat spesifik. 
Kebiasaan observasi yang anda refleksikan adalah kunci awal pertama anda dalam akumulasi pengetahuan anda yang dapat anda tuliskan dan bahkan dapat anda wujudkan dalam bentuk lain seperti perkataan anda dalam sebuah debat atau diskusi. Pentingnya observasi menjadi kebiasaan adalah anda akan cepat menangkap fenomena tertentu sehingga mampu menjernihkan kondisi rumit menjadi sebuah tulisan yang berbobot melalui sumber-sumber relevan yang telah terbiasa menjadi sumber verifikasi observasi anda.

Observasi adalah riset anda yang tidak hanya anda menafsirkan sebuah teks yang anda baca tapi juga dengan banyak hal lain di kehidupan selain itu pemahaman kontekstual juga harus dapat anda kembangkan. Bahkan observasi tidak akan menghasilkan apa-apa ketika anda tidak memiliki imajinasi tentang sebuah fenomena yang sedang anda perhatikan, misalkan anda sedang mengamati gerakan pemuda, imajinasi apa yang anda pikirkan, bisa seperti apa gerakan pemuda ke depannya? Apa saran imajinatif anda agar gerakan pemuda semakin progresif atau imajinasi lain? Sekali lagi ingat pesan Cak Lontong: Mikir!

Sebagai awal anda dapat melihat contoh tulisan yang eksis berkat observasi. Misalkan tulisan penulis sendiri tentang Ketimpangan Pelayanan Publik (Opini Harian Republika 13/03/2017) dimulai dengan hasil observasi pasca melihat sebuah film dokumenter.

Narasi Negara-Negara kesejahteraan di Benua Eropa dipertunjukkan dengan sangat menarik oleh Michael Moore dalam karya film Where to Invade Next (2015).............. (M. Rizki Pratama. 2017, Ketimpangan Pelayanan Publik, Opini Harian Republika 13/03/2017) 
Anda dapat melakukan banyak observasi untuk sebuah tulisan melalui berbagai cara-cara anda sendiri seperti melihat film, diskusi, membaca buku ataupun cara-cara kreatif anda sendiri seperti bersentuhan langsung dengan masalah di lapangan dan terlibat dalam penyelesaiannya.

\section{Kemampuan Mencatat}

Mencatat hal-hal penting merupakan satu titik lemah, kita sangat tergantung pada ingatan padahal kita juga sering lupa. Ingatan kita jelas terbatas sehingga kita harus mencatat setiap observasi yang kita dapatkan pada sistem pencatatan pribadi kita. Kenapa sistem? karena kita harus membuat sistem kita sendiri yang sesuai dengan kebutuhan kita termasuk dengan sistem tersebut kita akan mendapatkan kepastian sumber-sumber dengan lebih cepat dan akurat. Anda harus membuat database tulisan anda sendiri dengan berbagai sumbernya, jika terbiasa menulis di buku catatan maka khususkanlah buku catatan tersebut untuk topik tertentu dan jangan dicampur dengan yang lain.

Kemampuan membuat sistem pencatatan tersebut akan mempermudah kita dalam membuat tulisan. Kita dapat dengan mudah menemukan sumber, tidak mengulang pendapat orang lain dan bahkan dapat mengembangkan pendapat orang lain lewat bukti dari catatan kita.

Dalam konsep manajemen pengetahuan tentu harus terdapat sebuah database yang anda dapat anda panggil kembali ketika anda menginginkan informasi tertentu. Itulah guna kita mencatat tidak hanya untuk memgingatkan pada sesuatu akan tetapi juga meringkas sesuatu termasuk membuktikan validitas sumber kita. Misalkan penulis sendiri menggunakan Evernote untuk membuat catatan digital. Beberapa 
aplikasi lain seperti Mendeley untuk manajemen referensi juga diperlukan. Untuk manajemen proyek menulis yang dapat digunakan oleh kelompok juga dapat menggunakan aplikasi Trello. Masing-masing sudah banyak yang mengulasnya, cukup kita mencari lewat mesin pencari google.

Untuk mendukung catatan kita maka perlu sumber oleh karena itu anda penulis sarankan untuk memiliki menyimpan berbagai link berita penting berikut dalam browser ponsel atau laptop anda. Kita dapat membuat list daftar bacaan sehari-hari berbasis website dalam browser ponsel. Beberapa website berita dan studi bermutu yang wajib kita bookmark terutama dalam kita memiliki kajian minat ilmu sosial dan politik seperti antara lain:

1. Indoprogress (www.indoprogress.com). Jika berminat pada bahan kajian kritis dalam ilmu sosial, bacaan-bacaan dalam website ini sangat direkomendasikan. Sering terjadi debat berkelanjutan via tulisan dalam web ini yang sangat berguna untuk melatih logika kritis kita.

2. Tirto (www.tirto.id). Jika ingin mendapatkan berita dengan analisis mendalam disertai dengan data-data akurat yang berbeda dengan kanal berita arus utama, situs ini sangat direkomendasikan. Selain itu sajian grafis dalam situs ini juga sangat membantu kita untuk mempercepat pemahaman pada suatu masalah.

3. Vice (www.vice.com). Berita yang disajikan dalam kanal ini adalah sangat mendalam, unik dan populer. Berbeda dengan media mainstream kebanyakan, misalnya pernah mengulas kehidupan seorang Preman. 
4. Islambergerak (www.islambergerak.com). Konten dalam kanal ini berisi tulisan-tulisan untuk menuju islam yang progresif. Website ini dieditori oleh para aktivis seperti Roy Murtadho, Muhtar Habibie, dkk.

5. Geotimes (www.geotimes.com). Kanal ini sebagian besar berisi tulisan kolom dan opini para penulis. Kita dapat banyak belajar dari berbagai penulis dengan latar genre yang berbeda-beda, cukup dengan membaca tulisan mereka. Kita juga dapat mengirimkan tulisan untuk menguji kemampuan menulis kita dengan melihat seberapa banyak viewer yang kita dapatkan.

6. Project-Syndicate (www.project-syndicate.com). Kanal ini menyediakan ulasan-ulasan internasional tentang isu-isu terkini di seluruh dunia. Kita dapat membaca tulisan para pakar dunia, seperti Joseph Stiglizt, Dani Rodrik, Kinshore Mahbubani, Gordon Brown, Daren Acemoglu, dkk.

7. Blog Budisan (www.budisanblog.blogspot.com). Blog pribadi pak budi ini berisi ratusan artikel dokumentasi tulisan kolom dan opini pakar dari berbagai media masa nasional.

8. Historia ( $\underline{w w w}$.historia.id) Kanal penyedia konten-konten sejarah nasional dan internasional dengan data dan ilustrasi yang menarik. Dapat digunakan sebagai acuan untuk meluruskan sejarah. Misalnya tulisan tentang sejarah Soekarno, masa lalu Partai NU dan Gaj Ahmada dan Islam di Majapahit, dll.

9. Inside Indonesia (www.insideindonesia.org) Kanal ini menyediakan tulisan-tulisan dari sudut pandang para penulis di luar Indonesia. Misalnya baru-baru ini mereka mengeluarkan kumpulan tulisan tentang implementasi Undang-Undang Desa di Indonesia. 
10. New Mandala (www.newmandala.org). Kanal ini berisi hasil tulisan para pakar studi Asia Tenggara. Kita dapat membaca halhal terkini di dalam dan di luar Indonesia. Misalkan kondisi pemilu di Timur Leste, kontestasi Pilkada DKI Jakarta, konflik Rohingya, dll.

11. The Economist (www.economist.com). Jika tertarik dengan isuisu ekonomi internasional website ini sangat direkomendasikan. Tulisan yang disediakan mendalam, misalkan tulisan tentang isu-isu penarikan Obamacare, pemerintahan China, dll.

12. MIT Sloan Review (www.sloanreview.mit.edu). Jika kita tertarik dengan tulisan-tulisan manajemen, bisnis, psikologi dan statistik silahkan membaca website ini karena berisi ratusan artikel ilmiah tentang bidang studi tersebut.

13. Freiburg South Asian Studies (www.southeastasianstudies.unifreiburg.de). Situs ini merupakan hasil studi dari Universitas Freiburg tentang kajian Asia. Kita dapat menemukan berbagai tulisan berbagai persoalan di negara-negara di Asia yang diulas secara akademis.

14. Mongabay (www.mongabay.co.id). Tertarik dengan isu-isu lingkungan maka website ini patut kita baca. Media ini pernah mendapatkan penghargaan dari majalah TIME (2008) dan George Mason University (2010).

15. Mojok (www.mojok.co). Website ini juga merupakan gudang artikel dari berbagai penulis tulisan populer. Berbagai genre masuk dalam kanal ini, yang pasti kita dapat belajar dari bacaanbacaan segar. Bisa dibilang anti mainstream dengan judul-judul artikel yang menggoda misalnya empat aktor yang lebih cocok memerankan tokoh Dilan daripada Iqbal CJR atau yang 
sebaiknya anda lakukan jika punya duit 1,5 trilun atau rumah tangga terancam bubar karena nama anak.

16. East Asia Forum (www.eastasiaforum.org). Kanal ini berisi artikel mendalam dari Negara-Negara Asia Timur dan hubungannya dengan Negara lain. Artikel ditulis oleh para akademisi top sehingga layak untuk dibaca.

17. Kata Data (www.katadata.co.id). Kanal berita ini menyediakan kumpulan data statistik dari berbagai sumber dengan ilustrasi yang sangat menarik sehingga memudahkan kita untuk membaca dan memahami data.

18. Kumparan (www.kumparan.com). Situs ini selain menyediakan berita juga membuka story para kontributor baik dalam bentuk tulisan ataupun yang lain misalnya karya fotografi. Uniknya semua orang dapat menjadi kontributor sehingga tulisan-tulisan artikel banyak ditemukan disini, dengan berbagai genre, siap menjadi bahan bacaan untuk kita.

19. The Conversation (www.theconversation.com). Situs ini menghadirkan ulasan-ulasan mendalam baik tentang Indonesia juga internasional. Kelebihan situs ini adalah tulisan yang dihasilkan adalah dari berbagai pakar ataupun Indonesianis. Misalkan Yohanes Sulaiman, Ross Tapsell dari ANU, Tim Lindsey dari UNIMELB, David Hill dari Murdoch dan kawan-kawan.

\section{Menulis adalah Produk Latihan}

Menulis adalah sebuah kemampuan yang selalu kita asah, tak peduli usia anda memulai menulis. Mungkin ada dari kita yang memiliki bakat untuk menulis akan tetapi bakat yang tak diasah pasti akan salah jalur dan bahkan tergerus oleh mereka yang giat berlatih. Setidaknya tulislah sebuah paragraf setiap hari dengan minimal 3 hingga lima 
kalimat dengan sebuah ide yang kuat yang disokong argumen yang menarik. Lalu baca kembali dan segera tambal kekurangan kita. Jadikan latihan sebagai kebiasaan, semua tergantung kepada latihan menulis kita.

Anda bisa memulai suatu tulisan dengan topik menarik dan menjadi judul utama anda. Gambar 1.1 di bawah ini adalah sebuah contoh praktis yang penulis lakukan untuk menelurkan sebuah tulisan yaitu dengan membuat judul dalam file microsoft word. Anda dapat melihat bahwa sepanjang tahun 2017 ini penulis sudah membuat 250 judul tulisan, meskipun hanya sekitar 30\% yang benar-benar penulis selesaikan akan tetapi dengan menuliskan ide dalam judul dapat membuat langkah pertama latihan anda, tanpa topik maka tulisan anda tidak akan pernah ada.

\section{Gambar 1.1 List Judul Produk Latihan Tulisan}

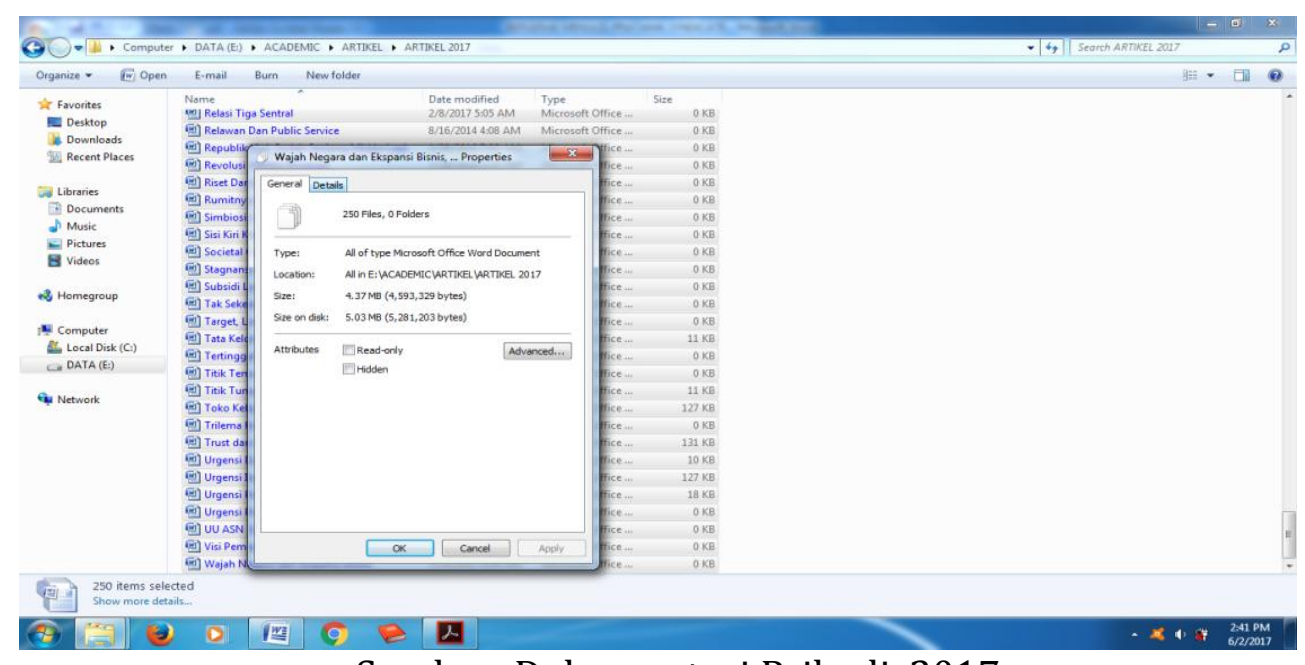

Sumber: Dokumentasi Pribadi, 2017 


\section{Pemahaman Karakter Artikel Ilmiah Populer}

Tulisan ilmiah populer juga dapat digolongkan sebagai tulisan non-fiksi kreatif sehingga kreativitas dalam tulisan kitalah yang akan diuji oleh para pembaca. Menurut Cheney (2001) Creative nonfiction tells a story using facts, but uses many of the techniques of fiction for its compelling qualities and emotional vibrancy. Creative nonfiction doesn't just report facts, it delivers facts in ways that move the reader toward a deeper understanding of a topic. Tulisan kita memiliki nilai emosional, tidak hanya melaporkan fakta akan tetapi juga memberikan pembaca sebuah pemahaman mendalam pada suatu topik. Selain itu terdapat beberapa karakter penting yaitu antara lain:

1. Karya ilmiah populer menggunakan bahasa lebih awam, membumi dan populer karena pembaca berasal dari seluruh kalangan bukan hanya kalangan komunitas epistemik.

2. Karya ilmiah menggunakan gaya bahasa yang lebih cair, ringan, semi formal dan persuasif.

3. Karya ilmiah populer digunakan untuk memberikan pemahaman kepada masyarakat awam atas fenomena tertentu.

4. Karya ilmiah populer lebih pendek jumlah katanya daripada karya ilmiah murni.

5. Contoh karya ilmiah populer dapat kita baca sehari-hari pada kolom dan opini pakar di media masa ataupun kanal-kanal kumpulan artikel populer lainnya misalkan di geotimes.

6. Karya ilmiah populer tetap berbasis fakta bukan fiksi. 


\section{Pemahaman Proses Penulisan}

Sebuah tulisan merupakan hasil dari proses yang iteratif atau siklis atau berupa siklus berputar yang tidak pernah selesai. Satu ide tulisan kita dapat berkali-kali direvisi menjadi tulisan baru. Bahkan kita masih dapat merevisi tulisan lama kita kembali untuk mengembangkan ide lama menjadi ide baru.

\section{Gambar 1.2. Proses Penulisan}

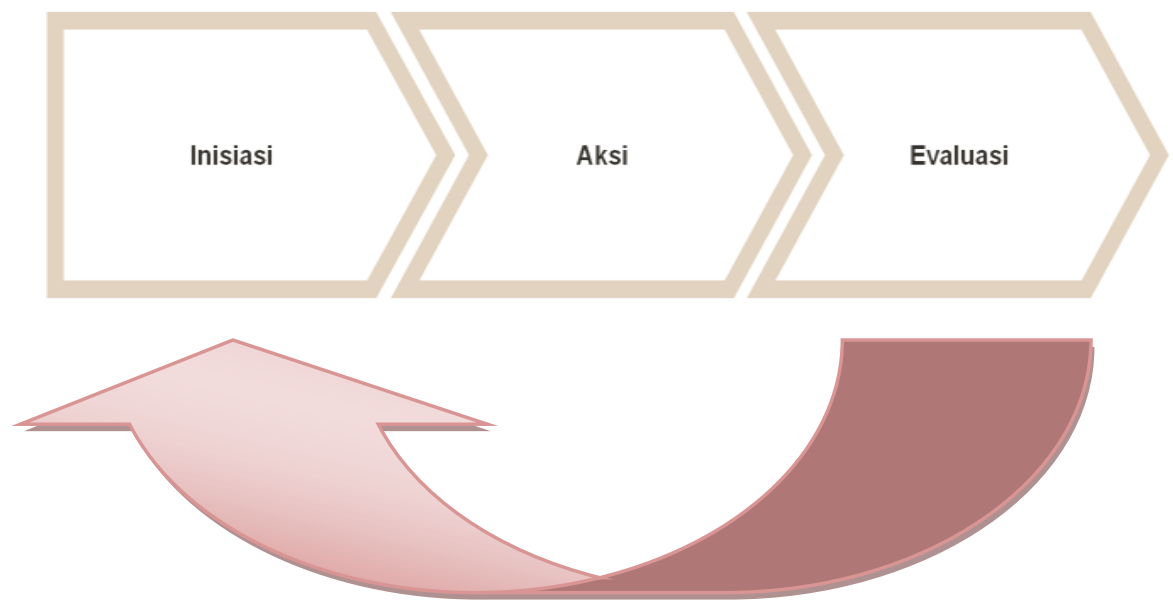

Seluruh bab dalam bundel ini ditulis dengan pendekatan proses, seperti kita lihat dalam gambar 1.2. Artinya pokok-pokok dalam menciptakan sebuah tulisan adalah sebuah tahapan-tahapan yang saling terkait. Lebih lanjut lagi tahapan tersebut tidak akan pernah selesai, misalkan setelah menyelesaikan sebuah tulisan anda dapat segera memperbaiki tulisan kembali, menambahkan bahan kembali, bahkan merubah judul anda ataupun merombak total karena argumen anda salah kaprah. Di lain waktu anda dapat juga merevisi tulisan anda kembali menjadi bentuk argumen lain, menambahkan hal-hal baru, mungkin saja juga menjadi inspirasi tulisan. Oleh karena itu sebuah 
tulisan apapun itu bentuknya, adalah cerita yang tak pernah selesai, selesai dalam teks tapi tak pernah selesai dalam pikiran anda.

Proses disini dapat dimaknai bahwa kita sebagai penulis harus melakukan tahapan berulang-ulang untuk memproduksi sebuah tulisan sekaligus melatih kemampuan. Proses juga harus kita lewati ketika kita harus menyadari bahwa kita bukanlah penulis yang sangat berbakat (termasuk penulis sendiri) sehingga perlu jatuh bangun merasakan sulitnya menuliskan ide-ide, mendapatkan cercaan bertubi-tubi hingga berkali-kali ditolak. Kita perlus berproses dalam menulis. Latihan akan membuat kita hebat dan yang sudah merasa memiliki bakat menulis tentu latihan akan membuat anda semakin cemerlang. 


\section{BAB II}

\section{INISIASI PENULISAN ARTIKEL}

Bab ini memberikan tahapan paling awal dalam menulis sebuah artikel. Berikut ini dapat dijelaskan beberapa segmen penting dalam mengawali sebuah tulisan. Tahapan ini secara normal dilakukan secara bertahap akan tetapi bukan sebuah metode baku, sebab tulisan adalah sebuah seni yang sangat tergantung pada intuisi kita dalam memulainya. Kita perlu membatasi topik tulisan, mencari ide dan menuliskan kerangkanya sebagai fondasi sebelum kita benar-benar menulis secara utuh dalam sebuah paragraf.

Sebelum kita melangkah lebih lanjut, perlu dipahami definisi awal tiga konsep penting, yaitu:

1. Topik Tulisan: Konsep sentral dalam sebuah tulisan. Contoh: Kemiskinan.

2. Tesis: Ide sentral dalam sebuah tulisan. Contoh: Kemiskinan di Indonesia tinggi karena lemahnya pendidikan.

3. Kalimat Topik: Ide sentral dalam sebuah paragraf yang berhubungan dengan tesis. Contoh: hubungan kemiskinan dengan pendidikan, kelemahan sistem pendidikan di Indonesia, urgensi perubahan pendidikan di Indonesia.

Tiga konsep tersebut akan sering muncul dalam keseluruhan bundel ini sehingga harus dikuasai definisi awalnya agar lebih mudah membaca berbagai deskripsi selanjutnya. Tiga konsep tersebut saling berhubungan menjadi sebuah kesatuan tulisan. Setelah menentukan topik dari bergerak ke tesis kemudian mencari argumennya dalam tiaptiap kalimat topik, agar lebih mudah dapat digambarkan dalam gambar 
2.1. Untuk selanjutnya tulisan agar langsung bergeser kepada perincian untuk menentukan topik tulisan dan mencari ide.

\section{Gambar 2.1. Contoh Tiga Konsep Penting Inisiasi}

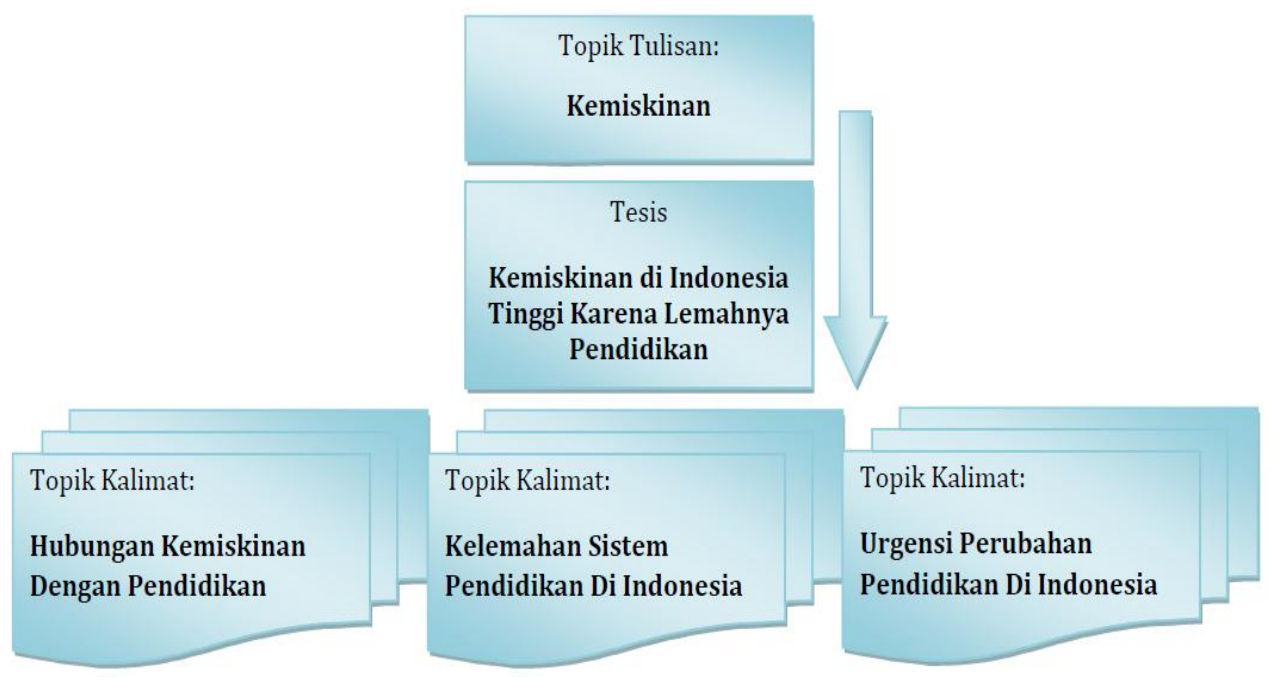

\subsection{Menentukan Topik Tulisan}

Topik tulisan adalah kosep utama/sentral/pokok dari sebuah tulisan atau pun dapat berupa pokok objek apa yang akan kita tuliskan. Banyak hal yang dapat digali dari sebuah topik akan tetapi lebih baik kita fokus pada topik-topik tertentu agar kita konsisten dan memiliki kedalaman penjelasan. Kita harus memilih topik kita sendiri sesuai dengan minat dan kemampuan kita. Sekali lagi jika minat dan kemampuan kita tidak menunjang jangan sekali-kali menulis topik tertentu, kita harus menyesuaikannya. Jika kita sedang tidak mempelajari bidang kesehatan maka jangan menulis topik seputar itu, ataupun soal topik motivasi padahal kita tidak pernah sekalipun membaca dan mengikuti seminar motivasi. 
Topik disini berguna untuk membatasi tulisan kita sehingga tidak melebar dan menjadi pintu masuk agar tulisan kita tajam. Topik dapat menjadi garis perjuangan kita untuk mencapai sesuatu misalkan anda berminat untuk menulis dengan topik-topik seputar korupsi, bisa jadi anda dapat menjadi aktivisi anti korupsi tulen, ataupun topik-topik tentang kepemudaan bisa jadi kita juga saat ini sejalan dengan garis pemikiran kita yang sedang giat menjadi aktivis pemuda. Setelah garis topik tulisan kita tentukan maka selanjutnya langkah yang paling penting adalah mencari ide-ide artikel.

\subsection{Mencari Ide Artikel}

Tahapan ini adalah salah satu bagian tersulit, bisa jadi anda sudah menyelesaikan $60 \%$ dari tulisan anda ketika mampu menentukan ide artikel anda yaitu tesis dan topik tulisannya. Oleh karena itu sangat penting untuk kembali pada fundamental penulisan artikel pada bab 1 . Terutama kepentingan anda, observasi dan catatan anda. Anda akan sangat cepat menemukan ide ketika tiga hal tersebut sudah anda lakukan secara rutin bahkan tanpa perlu paksaan alias menjadi kebiasaan.

Pada tahap ini penulis juga kesulitan untuk menuliskan pengalaman-pengalaman mencari ide sebab seringkali ide seperti eureka moment yang kadang muncul secara kebetulan dan tiba-tiba. Hal itu terjadi karena kita memang sudah terbiasa untuk mengobservasi fenomena tertentu sehingga secara cepat muncul penafsiranpenafisiran tertentu. Jika kita tidak terbiasa tentu akan sangat sulit dan lama untuk menelurkan sebuah ide orisinil. Proses mencari ide merupakan proses yang rumit dan sulit dijelaskan akan tetapi akan semakin mudah ketika kita sering mengobservasi dan mengeksplorasi topik-topik yang ada dalam minat dan kepentingan kita sehingga ide 
akanlah sangat cepat muncul dengan kadar pemahaman yang tinggi. Hal ini yang membedakan tulisan-tulisan pakar yang sangat spesialis karena sangat dekat dengan topik tertentu dibandingkan dengan kita yang baru saja mencoba memahami topik tertentu. Maka kita perlu fokus pada topik dan terus bergerak. Sekali lagi kunci ide adalah observasi! Apapun caranya.

Ide disini berarti kita sudah mulai menurunkan topik kita pada masalah-masalah tertentu yang terlihat pada permasalahan yang ingin kita jawab dan dugaan jawaban atas pertanyaan tersebut. jadi kita harus ingat bahwa ide selalu berbentuk kalimat yang lengkap atau komentar kita pada suatu fenomena yang akan kita buktikan derajat kebenarannya melalui argumen-argumen logis kita alias sebuah tesis. Seperti halnya kita memiliki komentar pada pengangguran di Indonesia yang disebabkan karena kurangnya jumlah wirausaha atau komentar kita pada kemiskinan akibat kesenjangan pembangunan.

Untuk mendukung tesis kita diperlukan argumen-argumen dengan informasi yang lengkap berupa topik-topik kalimat yan akan disusun dalam paragraf yang pada akhirnya akan membentuk sebuah tulisan utuh. Misalnya tesis bahwa pengangguran di Indonesia yang disebabkan karena kurangnya jumlah wirausaha didukung dengan berbagai ide sentral dalam paragraf berupa hubungan antara pengangguran dan kewirausahaan atau kemiskinan akibat kesenjangan pembangunan yang didukung oleh ide sentral bahwa industrialisasi selalu hanya menguntungkan orang kaya saja.

Memang terdapat perbedaan melalui sikap kita apakah ide kita mencoba membuat kondisi tertentu atau kondisi tertentu yang mendorong ide kita. Jika merujuk pada kondisi yang pertama maka tulisan kita akan lebih positivistik artinya ide-ide kita akan lebih banyak 
mengarahkan fenomena pada teori tertentu sebagai jawabannya. Jika lebih mengarah kondisi yang mendorong ide kita maka tulisan kita adalah tulisan yang lebih naturalis yang lebih menceritakan topik apa adanya. Untuk itu berikut ini adalah beberapa pertimbangan agar kita dapat menuliskan ide artikel.

\subsection{Pertimbangan dalam Mencari Ide Artikel}

Beberapa pertimbangan dapat dilakukan untuk dapat mencari ide-ide orisinil sebagai bahan utama tulisan kita yaitu antara lain:

\subsubsection{Karakter Ide Artikel}

Pertimbangan yang pertama adalah karakter ide artikel sendiri yang setidaknya mengangkat salah satu dari karakter di bawah ini:

1. Fenomena Baru. Artinya kejadian atau peristiwa yang anda angkat adalah hal baru yang belum pernah dituliskan sebelumnya. Seperti ratusan tulisan yang muncul dalam Pilkada DKI 2017, tulisan tentang pencabutan subsidi BBM, ataupun tulisan tentang kekerasan dalam dunia pendidikan belum lama ini hingga pembubaran HTI.

2. Data Baru. Anda dapat menyajikan data-data yang mendukung tulisan anda adalah data baru yang baru saja dirilis oleh berbagai lembaga kredibel, atau bahkan anda dapat melakukan riset anda sendiri yang tentu dapat anda pertanggungjawabkan sendiri. Data BPS adalah data yang banyak ditemukan dalam tulisan opini populer, misalkan data BPS baru tentang kemiskinan triwulan 1 tahun 2017, koefisien gini 2017 ataupun data angkatan kerja 2017. Banyak insitusi lain yang menyediakan data tinggal kita rajin menelusurinya seperti OXFAM dan Prakarsa tentang ketimpangan (2016) ataupun 
World Bank tentang The Rising Divide (2016). Kumpulan data berjumlah besar juga dapat kita temukan di website katadata.com. Data kualitatif berupa petikan wawancara juga dapat ditemukan. Banyak data pertebaran yang harus kita telusuri,

3. Perspektif Baru. Artinya memberikan pandangan lain pada suatu hal yang lebih segar. Bisa juga digunakan untuk meluruskan suatu masalah. Misalkan tulisan dari Mahfud MD, Saldi Isra dan Refli Harun biasa meluruskan masalah dari perspektif hukum. Tokoh lain yang intensif menghadirkan hal baru adalah Rhenald Kasali, pakar manajemen yang terus mendorong konsep disrupsi dalam beberapa tahun belakangan ini.

4. Sikap Kritis. Artinya memberikan pandangan kritik pada suatu entitias baik kepada pemerintah, masyarakat ataupun organisasi lain. Dalam model berbagai tulisan juga dapat dilakukan kritik terhadap tulisan penulis lain. Tulisan kritis dapat anda lihat dalam kanal indoprogress. Kanal tersebut juga menyediakan ruang bagi para penulis untuk saling mengkritik, bersahutsahutan via tulisan untuk kritik dan menanggapi kritik. Beberapa tulisan penulis juga mencoba mengkritisi pemerintah misalkan Pertumbuhan Ekonomi dan Pelayanan Publik (Opini Kompas, 2014).

5. Urgen alias Genting. Ide tulisan yang kita buat seharusnya memuat hal-hal penting yang harus segera ditindaklanjuti, jika tidak ada tindak lanjut maka masalah akan semakin meluas dan keadaan semakin rumit sehingga masyarakat semakin mengalami kerugian yang lebih besar. Ide kita dalam bentuk tulisan harus mampu menyerap kadar masalah yang dapat 
dijernihkan melalui tulisan. Misalkan untuk memberikan pengetahuan bagi masyarakat ketika terjadi wabah penyakit, atau bagaimana masyarakat harus bertindak ketika terjadi persekusi.

\subsubsection{Tujuan Umum Ide Artikel}

Pertimbangan lain adalah ide artikel yang kita tulis harus sesuai dengan tujuan umum yang menjadi preferensi kita sehingga ide dapat dipersempit atau diperluas sesuai dengan kebutuhan. Uco (2015) memberikan beberapa pertimbangan untuk sebuah tulisan ${ }^{1}$ yaitu antara lain:

\section{Monograf atau Survei}

Hal ini berarti tujuan umum penulisan kita ingin mendalami fenomena tertentu pada lingkup yang spesifik, khusus dan khas seperti tulisan tentang pengalaman mengajar di wilayah pegunungan tengger, ataupun tentang kehidupan warga area Lapindo. Sedangkan di bentuk lain kita ingin mencari generalisasi terhadap suatu fenomena dengan ketersediaan data-data umum seperti statistik yang berlaku pada populasi yang besar seperti Negara. Tulisan survei semacam ini biasanya miliki klaim yang luas dibanding monograf seperti kegagalan kebijakan ekonomi pemerintah ataupun kemiskinan perkotaan dan pedesaan.

\footnotetext{
1 Umberto Uco dalam How to Write a Thesis (2015) sebenarnya menggunakan pemilihan topik untuk tulisan tesis milik Umberto Uco akan tetapi dalam bundel ini hanya diambil 4 konsep menurut Uco yang sesuai dengan kebutuhan untuk penulisan artikel.
} 


\section{Historikal atau Teoritikal}

Hal ini berarti tujuan umum artikel kita berisi tentang sejarah suatu fenomena (historikal) atau penjelasan teoritis tentang fenomena tertentu. Misalkan kita akan menjelaskan tentang sejarah pendidikan tinggi di Indonesia daripada membahas manfaat pendidikan tinggi di Indonesia berdasarkan kajiankajian yang menghasilkan teori tertentu. Dapat pula sebaliknya.

\section{Kuno atau Kontemporer}

Hal ini berarti tulisan kita hendak menjelaskan fenomena masa lalu atau kuno seperti pengalaman para aktivis pada reformasi 98 sedangkan pada masa kini atau kontemporer seperti kehidupan aktivis di era media sosial.

\section{Keilmuan atau Politik}

Hal ini berarti tulisan yang kita buat memiliki tujuan benarbenar murni untuk pengembangan ilmu pengetahuan dan penyebarannya, memberikan para pembaca pemahaman tertentu pada suatu masalah seperti penjelasan tentang sistem politik di Indonesia dengan nuansa yang netral sedangkan jika tulisan kita bernuansa politik maka tujuannya adalah menjustifikasi sesuatu adalah salah dan benar untuk menggerakan perubahan. Biasanya tulisan sangat berpihak kepada golongan tertentu misalkan petani, buruh, dan kaum terpinggirkan lainnya. Topik yang bisa diangkan seperti reforma agraria dan anti penggusuran. 


\subsubsection{Observasi untuk Ide Artikel}

Untuk mencapai derajat ide yang kita inginkan tentu kita harus terus berlatih terutama untuk merenung dan memikirkan sesuatu. Kita perlu untuk semakin dekat dengan fenomena yang ingin kita tulis sehingga tulisan-tulisan kita tidak terasa dangkal dan memiliki keterkaitan dengan fenomena. Proses pendekatan tersebut dapat dilakukan dengan induksi melalui observasi.

Kita harus ingat bahwa setiap penulis memiliki cara sendiri untuk mendapatkan ide akan tetapi sebagaian besar dari mereka akan melakukan observasi. Observasi adalah hal yang wajib dilakukan oleh penulis apapun genre dan kemudian anda menuliskannya dalam sistem database milik anda. Cerita dari novelis Andre Hirata bahkan melakukan riset hingga 2 tahun untuk buku terbarunya. Sebagai awal sebagai seorang penulis pemula kita memerlukan berbagai cara untuk melakukan observasi setidaknya terdapat dua cara untuk melakukan observasi yaitu: pertama, observasi langsung dan yang kedua observasi tidak langsung. ${ }^{2}$ Berikut ini adalah penjelasannya:

1. Observasi langsung. Observasi ini berarti kita mendapatkan ide melalui tindakan kita secara langsung pada sebuah objek dari fenomena tertentu seperti berupa wawancara, pengamatan, keterlibatan langsung pada suatu masalah. Misalkan kita tengah melakukan pengamatan pada perilaku pelanggaran lalu lintas di lokasi tertentu, kemudian melakukan wawancara pada para pengendara dan kemudian ikut bergabung pada komunitas sadar lalu lintas.

\footnotetext{
2 Teknik observasi ini diambil dari metode penelitian kualitatif (silahkan baca lebih lanjut Creswell, 2010; Patton, 2009)
} 
2. Observasi tidak langsung. Observasi ini berarti kita mendapatkan ide melalui aktivitas kita yang tidak terlibat secara langsung dengan objek kita seperti membaca artikel koran, laporan penelitian milik orang lain dan membaca buku tentang fenomena tertentu.

\section{Tips Observasi Bahan Bacaan}

Memiliki sumber relevan dalam tulisan adalah hal yang wajib sebelum, sedang dan bahkan selesai menulis sebab dengan banyaknya sumber akan menguatkan argumen anda, menghindari kesalahan penggunaan konsep ataupun fakta dan bahkan mendapatkan inspirasi baru. Beberapa hal yang harus diperhatikan ketika mencari bahan bacaan antara lain:

Pertama, jika memang internet menjadi sumber utama dalam pencarian bahan anda maka pastikan situs-situs yang anda akses adalah kredibel seperti yang penulis contohkan dalam bab fundamental penulisan artikel.

Kedua, pastikan anda mencari siapa pakar di balik topik tertentu sehingga kita memiliki rujukan yang pas dan tidak salah orang. Untuk mencari pakar tersebut kita dapat melacaknya via mesin google, jika ingin lebih akademis gunakan saja google scholar dan cari pakar dengan sitasi (pengutipan) yang sudah banyak. Kita juga dapat menggunakan aplikasi manajemen referensi milik Mendeley. Silahkan google saja cara menggunakannya sebab sudah sangat banyak yang mengulasnya.

Ketiga, pastikan kita merujuk tulisan-tulisan tersebut dengan tata cara yang benar, ingat untuk tidak meng-copy paste tulisan orang lain. Hari-hari ini sangat mudah untuk melihat keaslian artikel misalnya dengan aplikasi Turnitin atau Viper. 


\section{Tips Mencatat Hasil Observasi}

Catatan merupakan rangkaian dari observasi. Catatan adalah hal yang sanat berguna terutama untuk memperkuat bahan bacaan ide artikel dan observasi ide artikel tanpa catatan maka kita tidak akan pernah ingat secara rinci apa yang telah kita baca dan observasi. Terdapat beberapa hal penting yang harus ada dalam sebuah catatan seperti yang dikutip dari materi Anne Whitaker (2010) yaitu:

Pertama, apa yang perlu kita dapatkan dari catatan hasil observasi:

1. Latar belakang informasi dari ide tulisan kita. Misalkan anda akan menulis tentang kemiskinan di Indonesia tentu kita perlu memeriksa sejarah latar belakang kemiskinan di Indonesia terlebih dahulu.

2. Argumen dan penjelasan yang mendukung atau menolak ide kita. Misalkan kita mendapatkan ide dasar bahwa kemiskinan datang dari kebijakan pemerintah yang tidak pro rakyat kecil, maka kita harus mencari argumen dan penjelasan yang mendukung ide kita tersebut dan mencari kritik atas ide tersebut guna menemukan perbaikan ide.

3. Dan yang paling dasar adalah kita harus menemukan fakta, contoh nyata, opini pakar dan dukungan detil-detil lainnya dalam topik tersebut. 
Kedua, cara membuat catatan:

1. Rangkuman, yaitu tulis ide utama dari sumber dalam kata-kata kita sendiri.

2. Parafrase, yaitu katakan kembali informasi penting dalam katakata kita sendiri; gunakan tanda kutipan jika kita mengutip secara langsung.

3. Kutip, yaitu kopi secara langsung kata-kata asli dari sumber.

4. Komentar, yaitu tulis berbagai pertanyaan dan ide ketika kita membaca sumber.

Setelah kita menemukan ide-ide awal kita melalu berbagai cara kemudian kita perlu memasak lagi ide kita agar semakin tajam oleh karena itu perlu memasak ide kita lebih lanjut.

\subsection{Memasak Ide Artikel}

Ide yang baik bukanlah ide yang berulang dan tentu tidak ada jawaban yang mudah. Kita dapat mendramatisir ide-ide kita dengan kata-kata bahwa hal tersebut penting untuk diungkapkan seperti jika tidak diungkapkan akan menimbulkan keresahan dan kerugian di masyarakat ataupun hal-hal lain yang dipandang urgen untuk segera diatasi. Tahapan memasak ide ini digunakan untuk mempertajam ide kita, beberapa cara dapat digunakan antara lain:

1. Pertanyakan kembali ide anda menggunakan $5 W+1 H$ yaitu What? When? Why? Who? Where? dan How?

Hal ini berarti kita kembali pada topik kita, kembali kepada apa topik kita? Kenapa kita membahas topik tersebut? konteks waktu kapan topik tersebut terjadi? siapa saja yang termasuk dalam topik tersebut? di mana topik tersebut terjadi? dan 
bagaimana kita membahas topik tersebut? kata bagaimana adalah ide orisinil kita dalam membahas topik tertentu.

2. Brainstrooming ide anda

Hancurkanlah ide anda sendiri untuk dapat menerima ide baru. hal yang sama juga dapat dilakukan dengan bantuan pihak lain misalkan dengan diskusi bersama teman-teman anda.

3. Kritisi dan sesuaikan konteks ide anda.

Kritik ide anda dengan berbagai cara terutama apa kelemahan ide anda, dan sesuaikan konteks pada setting apa akan membahas ide tersebut, seperti lokasi, ruang, waktu dan lain sebagainya.

4. Cara akademis.

Kita dapat juga merujuk cara-cara dalam dunia akademik, murujuk pada resep CARS (Creating Research's Space) John Swales (dalam Sword, 2012) dapat dilakukan 4 tahapan utama untuk menelurkan ide:

a. Tentukan area/topik penelitian.

b. Rangkum penelitian terdahulu.

c. Tunjukan bahwa penelitian terdahulu tidak lengkap.

d. Rubah gap ke dalam ruang penelitian untuk tulisan saat ini.

Selain itu dalam tulisan ilmu sosial setidaknya terdapat dua hal penting untuk membahas sebuah fenomena sosial yaitu: Pertama, ilmu sosial akan selalu menggambarkan sesuatu secara mendalam atau dalam istilah Clifford Geertz (1973) adalah thick description (deskripsi tebal) biasanya hasil sebuah pertanyaan adalah sebuah karakter, klasifikasi, golongan, pola tertentu dari fenomena misalnya penelitian Geertz tentang masyarakat Jawa yang terdiri dari priyayi, santri dan abangan. Selain itu juga studi kemiskinan dari Oscar Lewis (1969) juga memiliki 
penggambarkan tebal dari kemiskinan di Amerika Selatan yang mirip seperti Novel akan tetapi tetap akademis.

Kedua, ilmu sosial akan selalu menjawab pertanyaan kenapa sebuah fenomena terjadi (Meier, Brudney \& Bohte, 2012) dan jawabannya dalam ilmu sosial akan selalu tergantung pada kondisi tertentu dengan limitasi tertentu atau sangat tergantung pada konteks di mana data diambil (Lund, 2014). Data dan konteks yang tidak dapat dipisahkan adalah ciri khas ilmu sosial yang berbeda dari ilmu lain.

Untuk menjawab kenapa harus ada deskripsi terlebih dahulu tentang objek yang dibahas dan kemudian menjelaskan faktor-faktor yang menyebabkannya. Misalkan kenapa sebuah masyarakat menjadi miskin padahal terjadi industrialisasi? Untuk menjawabnya kita harus menjelaskan dulu apa itu kemiskinan, mengaitkannya dengan konteks industralisasi dan kemudian menjelaskan faktornya seperti rendahnya pendidikan, kurang akses keuangan dan lain sebagainya. Kita harus ingat bahwa tidak ada jawaban tunggal dalam ilmu sosial yang dicari adalah kedalaman penjelasan kita.

Mengingatkan kembali bahwa setiap ide dalam artikel harus berupa sebuah kalimat terbuka yang memungkinkan kita untuk dapat menjawabanya sesuai dengan kapasitas kita. Terbuka artinya kita harus siap menerima segala kemungkinan bahwa dalam perjalanan penulisan kita ternyata ide kita sudah usang dan perlu melakukan perubahan ide awal, atau ternyata ide kita sangat kontraproduktif dengan kenyataan saat ini, bahkan kita sama sekali tidak dapat menemukan rujukan yang sesuai, kita harus siap merubah ide awal kita. Sesuai kapasitas artinya kita harus mampu menjelaskan ide kita sesuai dengan kemampuan kita, 
tentu akan banyak hal yang diluar kemampuan kita, alhasil tulisan kita akan sangat kering dari penjelasan, dan akan mendapatkan feedback yang buruk.

Contoh nyata seperti ide yang datang dari minat kita pada topik masalah-masalah masyarakat perkotaan. Dengan pengalaman observasi dan dari catatan kita maka kita dapat menemukan ide baik topik tulisan, tesis dan topik kalimat tentang persoalan kemiskinan di perkotaan. Kemudian kita masak ide tersebut misalkan dengan kembali membaca literatur terkini yang kemudian menyempitkan ide kita pada persoalan kemiskinan perkotaan yang disebakan oleh ketimpangan sosial dan ekonomi ataupun kita mengambil perspektif lain misalnya kita akan mencoba menggambarkan pola-pola kemiskinan di perkotaan yang diperkirakan berbeda dengan kemiskinan di pedesaan. Dengan demikian ide kita sudah terbentuk dalam bentuk kalimat atau tesis atau hipotesis.

Kemudian persoalan alur ide apakah argumentasi ide disusun secara induktif atau deduktif itu memang terserah kita. Jika tulisan kita akan menempatkan ide pokok menjadi kesimpulan atau hasil akhir maka itu adalah logika induktif sebaliknya jika kita meletakkan ide pokok yang kemudian dirinci menjadi ide-ide penjelas lain maka menggunakan logika deduktif. Lebih ringkas menurut Popper (2002) induktif adalah singular statement (khusus) ke universal statement (umum) sedangkan deduktif adalah universal statement ke singular statatement.

Hal-hal tersebut akan berpengaruh pada cara membaca fenomena kita. Misalnya kita dapat menuliskan ide bahwa salah satu masalah perkotaan klasik adalah kemiskinan yang disebabkan oleh urbanisme tanpa kontrol sebenarnya kita dapat menyikapinya baik dengan logika 
deduktif maupun induktif. Logika deduktif tentu harus diawali dengan ide bahwa kemiskinan perkotaan disebabkan oleh berbagai faktor akan tetapi kemudian menurut argumen kita memilih urbanisme tanpa kontrol sebagai faktor penyebab utamanya sehingga tulisan kita berawal dari ide pokok umum ke ide yang khusus. Kemudian sebaliknya kita terlebih dahulu mengidentifikasi faktor-faktor apa yang sekiranya mempengaruhi kemiskinan perkotaan, tentu banyak hal akan tetapi kita harus merinci sesuai argumen kita untuk menuju faktor utama penyebab yaitu urbanisme misalkan rincian tentang jumlah pendatang yang semakin meningkat, banyaknya pendatang tanpa kompetensi yang memadai ataupun rendahnya pengawasan pendatang dari pemerintah hingga pada akhirnya kita dapat menyimpulkan bahwa ide pokok kita kemiskinan perkotaan disebabkan oleh urbanisme tanpa kontrol.

Untuk selanjutnya kita dapat mulai menuliskan blok-blok argumen dari ide kita dalam bagian selanjutnya yaitu menulis ide artikel.

\subsection{Model Menulis Ide}

Setelah ide dalam bentuk kelimat kita ketahui kita harus menyusun ide kita menjadi susunan argumen-argumen yang saling terkait. Terdapat dua model utama yang dapat dilakukan untuk menuliskan kaitan-kaitan pada ide kita dalam sebuah tulisan artikel, yaitu:

1. Model bertahap yaitu ketika menuliskan ide-ide kita dengan alur yang sudah jelas, dari ide yang satu ke ide selanjutnya secara bertahap. Memulai dengan ide yang besar kemudian ke arah yang lebih kecil ataupun sebaliknya. Dengan cara yang sama ide 
juga mengalir dari ide-ide yang sifatnya umum ke yang sangat khusus ataupun sebaliknya.

2. Model bebas yaitu ketika menuliskan ide-ide kita dengan alur yang tidak jelas, kita hanya menulis apa yang keluar dari kepala kita. Ide demi ide kita tuangkan ke dalam teks tanpa melihat runtutan tulisan yang kemudian baru kita satukan ketika kita sudah merasa mendapatkan poin-poin yang hendak kita sampaikan.

Khusus untuk model bertahap dengan struktur maka kita selanjutnya harus membuat sebuah kerangka tulisan. Akan tetapi tidak harus kita mengikuti pola ini sebab seperti yang sudah penulis katakan bahwa menulis adalah seni oleh karena itu beberapa dari kita tidak perlu membuat kerangkan tulisan dan langsung saja menulis seperti kata Andre Barahamin bahwa tujuan dari menulis adalah yang penting para pembaca benar-benar memahami penjelasan kita.

Kerangka Tulisan disini dapat menjadi dua bagian utama: pertama, kerangka tulisan berbasis ide dan kedua kerangka tulisan berbasis kategori.

Pertama, kerangka tulisan berbasis ide. Untuk menulis kerangka tulisan berbasis ide dapat menggunakan eksperimen model tesis. Tesis dapat berarti argumen, klaim, postulat, hipotesis ataupun asumsi kita pada masalah tertentu yang menjadi pusat utama tulisan. Model tesis ini akan mempermudah penciptaan ide-ide baru dalam otak kita. Setidaknya ada tiga hal penting yang dapat membuat tulisan kita memiliki tesis yang benar. Pertama, pertanyaan yang hendak akan kita jawab? Kedua, tesis alias jawaban atau dugaan atau argumen sementara yang dapat menyusun blok-blok argumen kita yang paling tidak hanya berupa satu kalimat dan Ketiga adalah argumen-argumen yang kita 
susun untuk mempertahankan tesis kita. Sebenarnya pertanyaan dan tesis dapat menjadi sebuah kesatuan akan tetapi dalam contoh ini akan dipisah untuk mempermudah klasifikasi.

\section{Contoh 1.}

\begin{tabular}{|ll|}
\hline Pertanyaan & : Apakah Indonesia berhasil dalam melaksanakan demokrasi? \\
Tesis & : Indonesia telah gagal melaksanakan demokrasi. \\
Argumen & : \\
1. Kesejahteraan tidak merata. \\
2. Korupsi di mana-mana. \\
3. Radikalisme merebak.
\end{tabular}

Contoh 2.

\begin{tabular}{ll}
\hline Pertanyaan & : Bagaimana pelaksaan program anti radikalisme pemerintah? \\
Tesis & : Program anti radikalisme jalan di tempat. \\
Argumen & $:$ \\
1. Program tidak efektif. \\
2. Program tidak merata. \\
3. Program terlalu elitis.
\end{tabular}

Contoh 3.

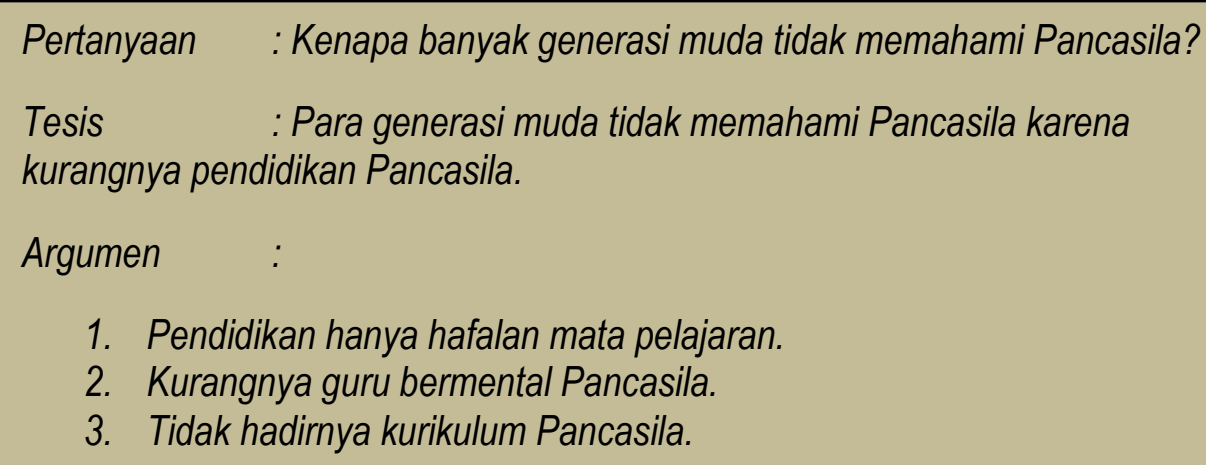

1. Pendidikan hanya hafalan mata pelajaran.

2. Kurangnya guru bermental Pancasila.

3. Tidak hadirnya kurikulum Pancasila. 
Contoh 4 .

\begin{tabular}{|ll|}
\hline Pertanyaan & : Kenapa program pemerintah banyak yang gagal? \\
Tesis & : Kegagalan program pemerintah karena tidak ada keterlibatan \\
masyarakat. & \\
Argumen & : \\
1. Program pemerintah didesain oleh para konsultan saja. \\
2. Program pemerintah tidak diawasi oleh masyarakat. \\
3. Masyarakat hanya sebagai subyek program. \\
\hline
\end{tabular}

Contoh 5.
Pertanyaan : Kenapa kerusakan lingkungan terus saja terjadi?
Tesis : Kerusakan lingkungan terjadi karena kesalahan bersama
Argumen
1. Kesalahan pemerintah dalam menetapkan standar dan pengawasan.
2. Kesalahan perusahaan karena membuang limbah sembarangan.
3. Kesalahan masyarakat karena tidak peduli dengan lingkungan sekitar.

\section{Contoh 6.}

Pertanyaan : Kenapa angka pengangguran di Indonesia tinggi?
Tesis : Angka pengangguran selalu tinggi karena pendidikan tidak
menjamin pekerjaan.
Argumen :
1. Pasar tenaga kerja tidak sesuai dengan kurikulum pendidikan dan
sebaliknya.
2. Pendidikan secara umum tidak banyak membantu persoalan teknis.
3. Pendidikan hanya fokus duduk di sekolah bukan menyelesaikan
persoalan masyarakat.


Model tersebut sangat membantu dalam langkah awal menulis, dan disepanjang perjalanan kita menulis semua masih dapat berubah akan tetapi dengan adanya alur pemikiran yang jelas dan disokong argumen yang masuk akal maka perubahan bukanlah masalah besar. Ini yang dimaksud sebagai eksprimen model tesis karena anda akan menguji coba argumen sentral anda sendiri sepanjang waktu dan akan dapat berubah ketika anda menulis berdasarkan akumulasi pengetahuan.

Kedua, kerangka tulisan berbasis kategori. Secara cepat dan sederhana anda dapat membuat sebuah abstrak dari rencana tulisan kita, yaitu terdiri dari masalah apa yang hendak dikaji, pendekatan apa yang kita pakai sebagai pisau analisis, argumen apa yang kira-kira dapat mendukung pernyataaan kita serta perkiraan kesimpulan. Cara ini merupakan bentuk modifikasi dari abstrak penelitian ilmiah akan tetapi yang kita tiru adalah alur dan formasinya bukan konten ilmiah yang lebih ketat. Untuk kerangka tulisan berbentuk kategori merupakan sebuah metode membagi keseluruhan tulisan menjadi tiga kategori utama, yaitu pertama pendahuluan, pembahasan dan penutup.

Pendahuluan berisi pengantar topik tulisan, kemudian mengarah ke ide berupa masalah dan tesisnya. Lalu pembahasan berisi analisis yang menghubungkan antar poin argumen yang tercermin dalam topik tulisan dengan jawaban lalu penutup yang berisi kesimpulan atas jawaban yang telah dianalisis. Sebenarnya ada banyak model yang dapat digunakan akan tetapi secara lebih ringkas hanya tiga kategori saja. Ketiga kategori utama tersebut menjadi dasar utama dalam setiap tulisan artikel yang harus tertanam di kepala kita dan menjadi sebuah langkah otomatis ketika akan menulis. 


\subsection{Menulis Judul}

Untuk membantu memberikan sedikit dasar tentang membuat judul maka terdapat beberapa unsur penting. Judul tentu harus merepresentasikan isi keseluruhan. Beberapa unsur karakteristik penting dari judul yaitu antara lain:

1. Menarik. Dalam artian menggugah minat pembaca pada kesan pertama atau ketika anda sendiri membaca tulisan anda sendiri maka anda akan merasa tergelitik untuk membacanya. Menarik berarti membuka keingintahuan pembaca (apa itu maksudnya?).

2. Singkat. Dalam artian judul setidaknya hanya terdiri dari maksimal dua baris kalimat. Bahkan banyak sekali judul artikel hanya terdiri dari satu hingga tiga kata.

3. Fokus. Dalam artian judul anda memang dibuat untuk menjelaskan tulisan bukan yang lain. Seringkali judul ternyata tidak mampu mengcover keseluruhan isi tulisan. Spefisik berarti fokus dengan lingkup yang sangat kongkrit.

Untuk membuat judul dengan tiga karakter diatas maka dapat dilakukan beberapa teknik berikut yaitu antara lain:

\section{Teknik Reduksi}

Teknik membuat judul untuk artikel populer yaitu dengan menggunakan cara reduksi atau penyederhanaan atau simplifikasi. Cara ini dilakukan untuk membuat judul awal kita menjadi menarik, singkat dan fokus. Cara ini hanya dapat dilakukan ketika anda menulis judul sebelum menyelesaikan tulisan artinya judul dibuat di awal pengerjaan bukan di akhir. Ketika menulis judul yang pertama kali dilakukan adalah anda 
pasti membuat judul yang sangat umum dan luas cakupannya oleh karena itu anda perlu menurunkan cakupan judul anda baik konsep, ruang, dan waktu sehingga dapat menghasilkan judul yang lebih baik.

Misalnya judul awal anda adalah "Dampak Kapitalisme pada Negara." Judul tersebut masih sangat umum oleh karena itu perlu diturunkan. Misalkan dampak kapitalisme menjadi lebih kongkrit dan jelas subjeknya yaitu menjadi "Jatuh Bangun Kaum Miskin atau "Pemiskinan Rakyat lewat Infrastruktur" atau "Tipu Daya Perusahaan bagi Pekerja Kontrak" atau "Mahasiswa Miskin diantara Mewahnya Gedung Kuliah dst. Sedangkan Negara dapat diturunkan juga menjadi misalkan di pinggiran Kota $\mathrm{x}$ atau di Pedesaan Kota $\mathrm{x}$ atau di grup perusahaan $\mathrm{x}$ atau di Universitas $\mathrm{x}$. Kesimpulannya bahwa hanya dengan lebih fokus dan menyempitkan konsep maka judul anda dapat berubah secara drastis. Pada akhirnya terbukti bahwa dari satu judul awal tersebut dapat menjadi empat judul yang lebih kongkrit.

\section{Teknik Kontradiksi}

Metode ini seringkali digunakan untuk menarik pembaca karena judul yang kontroversial sehingga membuat pembaca sudah ingin berkomentar ekstrim seperti sangat mendukung ataupun sangat membantah bahkan sebelum membaca tulisan secara utuh. Misalkan judul-judul artikel yang saling berlawanan dalam kalimatnya seperti "Kesederhanaan Hidup Para Pejabat Birokrasi" atau "Produktifnya Anggota Dewan Kita" atau "Koruptor Tidak Perlu Dipenjara." 


\section{Teknik Potong}

Metode ini biasanya menggunakan kalimat yang belum selesai, misalkan menggunakan tanda tanya pada akhir kalimat ataupun titik-titik pada akhir kalimat. Hal tersebut dilakukan untuk memantik minat membaca untuk menelusuri tulisan lebih jauh lagi. Seperti judul-judul "Masihkah Kita Perlu Merayakan Hari Kemerdekaan?" atau "Minimalitas Prestasi DPR, Salah Siapa?."

\section{Teknik Modifikasi}

Metode ini adalah metode yang paling sederhana, bukanlah sebuah plagiarisme karena kita akan memodifikasi judul-judul tulisan yang sudah terbit dengan ide kita sendiri. Sering sekali ada judul artikel dengan kata sambung “dan' di tengah kalimat, bisa terdiri dua kata atau lebih yang menghubungkan kata-kata tersebut. Misalkan ada pakar pembangunan yang menulis "Pembangunan dan Korupsi" atau tiga kata dengan "Globalisasi, Disrupsi dan Desa Kita" kemudian kita memiliki minat pada topik tentang kemiskinan maka kita dapat memodifikasi judul-judul tersebut menjadi "Pembangunan, Korupsi dan Kemiskinan" atau "Disrupsi dan Kemiskinan Desa Kita."

Selain itu terdapat juga tambahan dari James Hartley dalam sarannya menuliskan bahkan dalam judul-judul riset ilmiah pun dapat menggunakan bahasa-bahasa yang tidak terlalu formal atau baku dengan tujuan untuk memberikan rasa dan menarik pembaca. Hartley (dalam Sword, 2012) memberikan contoh untuk mendapatkan cara yang paling sederhana dalam menulis judul yang menarik dan informatif adalah dengan menggabungkan dua frasa berbeda, satu menarik dan selanjutnya informatif atau dengan kata lain satu catchy 
dan selanjutnya deskriptif. Misalnya menurut penulis berupa judul berikut ini: "Matinya Nalar Pendidikan Kita: Analisis Kritis Pada Sistem Kurikulum Pendidikan Tinggi" atau "Orang Miskin Dilarang Sakit: Menguji Dampak Ketimpangan Pelayanan Kesehatan di Era JKN" atau "Menebas Beton Hirarki Birokrasi: Merunut Sejarah Reformasi Birokrasi di Indonesia." 


\section{BAB III}

\section{AKSI PENULISAN ARTIKEL}

Bab ini merupakan tahapan paling penting dalam pendekatan proses menulis sebab dalam bagian inilah tulisan harus benar-benar sudah terbentuk dan dapat dibaca dalam bentuk kalimat-kalimat dalam paragraf. Terdapat empat elemen penting dalam bab ini yaitu dasar menulis paragraf, menulis pendahuluan, analisis dan penutup dalam sebuah topik tulisan.

\subsection{Dasar Menulis Paragraf}

Menulis sebuah paragraf merupakan bentuk nyata dari sebuah tulisan, setiap paragraf merupakan poin-poin yang menjelaskan ide-ide kita. Bagian ini diperuntukan sebagai dasar dalam menulis paragraf yang baik, termasuk dasar dan teknik menulis paragraf.

\subsubsection{Struktur dan Karakter Paragraf}

Untuk menulis paragraf terdapat beberapa konsep spesifik paragraf yang seharusnya kita pahami agar tulisan kita jelas sehingga dapat diterima oleh pembaca. Berkaitan dengan struktur sebuah paragraf sendiri setidaknya sebuah harus memiliki tiga elemen berikut yaitu:

1. Kalimat Topik: ide sentral berupa kalimat dalam sebuah paragraf.

2. Kalimat Pendukung: kalimat yang mendukung kalimat topik.

3. Kalimat Kesimpulan: kalimat keputusan akhir yang diperoleh berdasarkan metode tertentu. 
Selain itu masih terdapat struktur lain beruapa paragraf normal (Cardiff Metropolitan University, 2016). Setidaknya terdiri dari 6 titik tumpu yaitu: 1) Topic Sentence: Topik tulisan kita. 2) Discourse/Debate: perdebatan yang terjadi pada topik tersebut. 3) Your View: pandangan kita atau posisi kita. 4) Supporting Evidence: bukti pandangan kita atau posisi kita. 5) Evaluative Judgement: penilaian kita berdasarkan buktibukti yang ada. 7) Signpost Next Paragraph: kalimat transisi untuk menunju paragraf selanjutnya. Berikut ini adalah contoh penggunaannya:

\section{Strategi Pelayanan Kesehatan di Era BPJS ${ }^{3}$}

Topic Sentence

Era Kesehatan Universal telah berlangsung di Indonesia dengan keluarnya UU JKN 2013 Silam.

Discourse/Debate

Sejauh ini banyak kritik yang berlangsung, misalkan studi dari pakar $x$ menunjukkan aksesibilitas BPJS masih kurang. Sedangkan studi dari y yang sejak awal mengkritik model asuransi kesehatan nasional mengatkaan bahwa rakyat tidak hanya butuh kesehatan univerasal akan tetapi juga kualitas pelayanan publik universal.

View

Kritik memang diperlukan untuk membangun asuransi kesehatan yang lebih baik akan tetapi kinerja asuransi juga jangan luput dari apresiasi.

Supporting Evidence

BPJS hingga 2017 ini memberikan cakupan 70\% dan menjadi badang pengelola asuransi kesehatan terbesar di dunia sehingga pada dasarnya organisasi memiliki beban kerja yang berat, disamping tuntutan eksternal baik dari pemerintah atauapun masyarakat sendiri.

\footnotetext{
${ }^{3}$ Semua data di bawah yang digunakan masih bersifat imajinatif bukan fakta, hanya untuk kepentingan pembelajaran.
} 


\section{Evaluatif Judgement}

Berbagai tantangan berat yang muncul seharusnya menjadi titik awal untuk tetap meningkatkan kinerja.

Signpost Next

Perlu strategi lebih lanjut untuk meng-handle tantangan organisasi.

Topic Sentence

Strategi BPJS dalam menghadapi tantangan kedepannya dimulai dengan menata internal organisasi.

Discourse/Debate

Pada dasarnya mereka menggunakan pendekatan x daripada y seperti disebutkan dalam studi prof x. konsekuensi-konsekuensi yang muncul akibat pendekatan tersebut adalah kurang adaptifnya pada perubahan eskternal sebab strategi yang dilakukan mengabaikan persaingan.

View

Pada dasarnya memang organsiasi BPJS dianggap tidak perlu lagi mencari nasabah asuransi karena warga negara wajib untuk beraptisiapsi, akan tetapi problem aksesibiltas yang sering menganggu kebijakan publik di Indonesia sehingga diperlukan startegi internal untuk meningkatkan aksesibiltas pengguna.

Supporting Evidence

BPJS ekspansif membangun berbagai macam unit akses untuk meningkatkan aksesibilitas pengguna di berbagai daerah disamping berbagai stragei lain seperti handling complain, kemudahan pembayaran iuran, dan pendataan door to door.

Evaluatif Judgement

Sejauh ini strategi intenal memang telah bekerja akan tetapi untuk menghadapi perubahan masyarakat seharusnya diperlukan strategi lain yang lebih komprehensif berbasis kebutuhan publik sebab dinamika di luar organisasi adalah sangat ekstrim. Baru-baru ini saja asuransi kesehatan Obama Care dengan mudahnya ditarik oleh rezim Trump.

Signpost Next

Strategi-strategi selanjutnya dapat mempertimbangkan analisis eksternal berbasis kebutuhan publik. 
Contoh paragraf tersebut sebenarnya berusaha untuk saling mengkaitkan antara kalimat satu dengan kalimat lainnya serta paragraf satu dengan paragraf lainnya sekaligus berkaitan dengan topik. Seringkali kita sendiri gagal untuk menyediakan hal tersebut misalkan transisi antara satu kalimat dengan kalimat lain terlihat terpotong atau kurang smooth termasuk paragraf satu dengan yang laing tidak nyambung. Hal-hal tersebut haruslah kita perbaiki karena akan semakin sulit bagi pembaca untuk memahami tulisan kita. Jadi kita harus benar-benar memperhatikan kaitan kalimat dan paragraf dengan merasakan transisi atau perpindahan antar kalimat dan paragraf.

Masih terdapat jenis struktur paragraf lain juga dapat digunakan yaitu berdasarkan konten kalimat paragraf itu sendiri, setidaknya terdapat lima jenis struktur paragraf (Lele et al, 2010) yaitu:

1. Kronologi. Karakteristik utama paragraf kronologi adalah gagasan yang berbasis sekuen waktu (time line). Urutan waktu yang paling penting dalam paragraf kronologi ini seperti ketika kita menuliskan sejarah perjuangan kemerdekaan Indonesia lengkap dengan tahunnya.

2. Deskripsi. Jenis paragraf deskripsi bertujuan untuk menggambarkan suatu fenomena secara detail tanpa asumsi sebelumnya. Paragraf ini juga memberikan penggolongan atau kategorisasi tertentu pada sebuah fenomena yang bukan berdasarkan penggolongan atau kategorisasi yang kita buat sendiri akan tetapi memang apa adanya dunia di luar kita. Seperti ketika kita menuliskan rincian dari sebuah rumah tua yaitu kotor, lembab, tidak terawat, menyeramkan, dst. 
3. Sebab-Akibat. Logika pikir yang mendasari penulisan paragraf sebab-akibat adalah hubungan satu isu atau fenomena dengan isu atau fenomena lain. Misalnya kita menjelaskan hubungan antara pendidikan dengan kemajuan Negara, semakin banyak rakyat yang berpendidikan tinggi maka Negara akan semakin maju.

4. Perbandingan. Paragraf perbandingan bertujuan untuk membandingkan dua hal atau lebih. Paragraf ini dapat digunakan untuk menunjukkan kondisi dan konteks fenomena di tempat lain dengan apa yang terjadi di tempat kita. Misalnya ketika kita menulis masalah transportasi di Indonesia maka kita dapat memperbandingkan dengan apa yang terjadi di Singapura, Malaysia ataupun Negara-Negara lainnya.

5. Evaluasi. Paragraf evaluasi bertujuan untuk memberikan penilaian (judgement) terhadap kebijakan atau program yang dievaluasi. Paragraf ini harus disertai dengan dasar penilaian yang jelas pada suatu kondisi yang akan dinilai, misalnya kita pernah mengenal kebijakan Bantuan Langsung Tunai (BLT) maka indikator apa yang sesuai untuk menilai kebijakan tersebut berhasil atau gagal, dapat digunakan seperti aspek ketepatan sasaran dan besaran nilai BLT sendiri, jika bantuan tidak tepat sasaran dan nilai bantuan sangatlah kecil maka dapat dinilai atau dievaluasi bahwa kebijakan adalah gagal. 
Selain itu agar tulisan kita menjadi semakin baik maka kita harus benar-benar memahami karakter paragraf sendiri yang terdiri dari tiga elemen penting, yaitu:

Pertama, kesatuan (unity) yaitu seluruh paragraf berkaitan dengan tesis jika berbicara tulisan secara keseluruhan dan seluruh kalimat berkaitan dengan topik kalimat jika berbicara tulisan dalam paragraf. Dua hal tersebut harus saling berkaitan dari awal hingga akhir tulsan. Kunci dari kesatuan adalah ide yang saling berkaitan antar paragraf ke arah tesis kita, tidak melebar kemana-mana atau fokus pada poin tesis kita.

Kedua, koherensi (coherence) yaitu keseluruhan paragraf disusun secara logis, teratur dan konsisten dan seluruh kalimat juga demikian. Kunci dari koherensi adalah transisi antar paragraf ke paragraf lainnya dan antar kalimat ke kalimat lainnya terasa mudah dibaca, tidak melompat-lompat dan jelas alurnya.

Ketiga, pengembangan (development) yaitu tersedianya informasi yang cukup bagi pembaca dalam sebuah diskusi dalam tulisan baik dalam kalimat dan paragraf. Pengembangan adalah pendukung utama dalam tesis kita sehingga akan terlihat benar logika kita dalam menulis seperti bagaimana kita menganalisis, menjelaskan, ataupun membandingkan berbagai informasi tertentu. 


\section{Tips Pengembangan Paragraf}

Penulisan dalam paragraf memerlukan strategi tertentu yang sesuai dengan kebutuhan kita dalam menjelaskan ide-ide kita. Berbagai cara tersebut dapat membantu kita untuk memperkuat argumen yang menjelaskan tesis. Strategi tersebut dapat ditulis oleh Nordquist (2017) dan dapat dilihat di laman ThoughtCo, sebagian disajikan disini sebagai bahan pembelajaran yaitu:

1. Elaborasi: menunjukkan rincian dengan memberikan definisi atau dengan mengklarifikasi dan menambahkan informasi penting.

2. Ilustrasi: memberikan gambar verbal yang membantu membuat atau mengklarifikasi poin kita. Potongan yang dilustrasikan dengan baik lebih mudah untuk dibaca daripada yang mengikuti abstraksi tingkat tinggi.

3. Narasi: menghubungkan perkembangan sejarah dari fenomena tertentu.

4. Deskripsi: menggambarkan tanpa kategori sebelumnya atau apa adanya.

5. Klasifikasi: mengorganisasikan fenomena atau ide pada kategori yang lebih luas yang menunjukkan karakteristik yang sama.

6. Analisis: membagi fenomena atau ide ke dalam elemen.

7. Proses: menunjukkan cara bekerjanya sesuatu.

8. Relasi: menunjukkan korelasi dan penyebab (hati-hati terhadap logical fallacy)

9. Perbandingan dan kontras: menunjukkan persamaan dan perbedaan diantara dua atau lebih. 
Jadi dengan menggunakan cara tersebut sebuah paragraf kita akan memiliki tujuan sesuai dengan kalimat topik masing-masing. Misalkan kita mempunya kalimat topik inovasi sektor publik lalu kemudian kita mencoba mengilustrasikannya dengan berbagai gambaran verbal tentang apa itu inovasi sektor publik lalu kemudian dalam paragraf berikutnya mencoba menjelaskan prosesnya lalu paragraf berikutnya menunjukkan sebab-sebab munculnya inovasi sektor publik dan seterusnya. Cara pengembangan paragraf ini sangat membantu kita terutama ketika mengalami kebuntuan tentang apa lagi yang harus ditulis.

Selain itu berbagai hubungan berikut melalui hubungan semantik Spradley (1979) seperti dalam tabel 4.1. dapat menjadi pijakan untuk mengembangkan kalimat dalam sebuah paragraf. Masing-masing hubungan akan memberikan petunjuk awal tentang bagaimana tulisan kita diarahkan. Berbagai hubungan tersebut akan sangat memudahkan kita untuk menulis sebuah kalimat yang jelas pengembangannya. Anda akan terus dapat menulis apapun itu dengan hanya menuruti berbagai hubungan di bawah ini sesuai dengan tesis yang anda tulis. Misalkan anda memulai dengan hubungan penyebab-pengaruh atau alasan atau yang lain, sesuai dengan kebutuhan kita,

Misalkan kita memulai kalimat topik yang sama yaitu inovasi sektor publik kita dapat mengembangkannya dengan berbagai transisi yang jelas yaitu bisa kita mulai dengan jenis-jenis inovasi sektor publik, kemudian fungsi inovasi sektor publik, tahapan-tahapan apa saja yang terjadi serta karakter apa saja yang melekat pada inovasi sektor publik. 
Tabel 4.1. Hubungan Semantik Spradley (1979)

\begin{tabular}{|l|l|l|}
\hline Tipe Hubungan & Sifat Umum Hubungan & \multicolumn{1}{|c|}{ Contoh } \\
\hline 1. Inklusi ketat & X adalah jenis dari Y & $\begin{array}{l}\text { Susu adalah jenis } \\
\text { makanan }\end{array}$ \\
\hline 2. Spasial & $\begin{array}{l}\text { X adalah tempat dalam Y } \\
\text { atau X adalah bagian } \\
\text { dari Y }\end{array}$ & $\begin{array}{l}\text { Dapur adalah sebuah } \\
\text { ruangan di rumah }\end{array}$ \\
\hline $\begin{array}{l}\text { 3. Penyebab- } \\
\text { Pengaruh }\end{array}$ & $\begin{array}{l}\text { X adalah hasil dari Y atau } \\
\text { X adalah penyebab dari Y }\end{array}$ & $\begin{array}{l}\text { Makan adalah penyebab } \\
\text { dari rasa kenyang }\end{array}$ \\
\hline 4. Alasan & $\begin{array}{l}\text { X adalah alasan untuk } \\
\text { melakukan Y }\end{array}$ & $\begin{array}{l}\text { Membutuhkan uang } \\
\text { adalah alasan untuk } \\
\text { bekerja }\end{array}$ \\
\hline 5. Lokasi & $\begin{array}{l}\text { X adalah tempat untuk } \\
\text { melakukan Y }\end{array}$ & $\begin{array}{l}\text { Sekolah adalah tempat } \\
\text { untuk belajar }\end{array}$ \\
\hline 6. Fungsi & X digunakan untuk Y & $\begin{array}{l}\text { Uang digunakan untuk } \\
\text { membeli makanan }\end{array}$ \\
\hline 7. Cara-tujuan & $\begin{array}{l}\text { X adalah cara untuk } \\
\text { melakukan Y }\end{array}$ & $\begin{array}{l}\text { Bekerja keras adalah } \\
\text { cara untuk mendapatkan } \\
\text { kemajuan }\end{array}$ \\
\hline 8. Tahapan & $\begin{array}{l}\text { X adalah tahapan dalam } \\
\text { Y }\end{array}$ & $\begin{array}{l}\text { sekolah adalah tahapan } \\
\text { untuk menjadi pintar }\end{array}$ \\
\hline 9. Atribut & X adalah karakter dari Y & $\begin{array}{l}\text { Rela berkorban adalah } \\
\text { karakter dari pemimpin }\end{array}$ \\
\hline
\end{tabular}

Sumber: Spradley (1979) dalam Whitehead, 2005.

\subsubsection{Saran-Saran Menyusun Paragraf}

Elemen-elemen sebelumnya harus benar-benar kita kuasai agar paragraf yang akan kita tulis sesuai dengan keinginan kita dan memudahkan pembaca untuk memahami. Jika kita sama sekali tidak memiliki pijakan dasar menulis yang benar maka kita tidak akan memiliki bayangan seperti apa nanti tulisan kita, justru berakhir pada tidak terwujudnya tulisan kita, akan tetapi sejatinya masih sangat banyak saran-saran dari para penulis berpengalaman dalam menulis sebuah paragraf misalkan saran dari Paula J. Silvia (2007) dalam menulis, yaitu: 
1. Gunakan kata yang baik artinya kita harus tahu makna dan rasa dari kata-kata yang kita pilih dalam sebuah kalimat.

2. Tulis kalimat yang kuat artinya kita dapat menuliskan kalimat dengan struktur paralel yang menunjukkan hubungan, kontras, perbandingan sehingga saling terkait dan berhubungan.

3. Hindari frasa pasif, lemah dan terlalu panjang

4. Menulis adalah yang pertama dan revisi kemudian, artinya jangan menulis sekaligus merevisi karena akan mengurangi fokus dan memperlambat pikiran kita.

Selain itu juga terdapat saran oleh William Zinsser (2005) yang menurutnya terdapat dua metode penting yang harus diingat oleh penulis, yaitu:

1. Kesatuan, artinya penulis harus memahami kemana arah tulisannya sendiri? tentu untuk menjawab masalah yang diajukan dalam tulisan. Sejauh mana masalah hendak penulis selesaikan? yaitu berkaitan sedalam apa penjelasan yang akan kita berikan. Satu poin apa yang akan penulis ajukan? yaitu poin terkuat mana yang harus penulis ajukan sebagai pendapat utama. Tulisan harus provokatif atau dalam bahasa tulisan kanal geotimes adalah harus ada call for action.

2. Pembukaan dan Penutupan. Bagian artikel yang paling penting adalah kalimat pertama. Menarik minat pembaca dengan kesegaran atau kebaruan atau paradoks atau atau humor atau kejutan atau ide aneh atau fakta menarik atau sebuah pertanyaan. Ketika kita siap untuk menutup tulisan makan tutuplah, tunjukan seluruh fakta dan poin yang ingin kita katakan, selesaikan. 
Kemudian Helen Sword (2012) memberikan saran yang lebih rinci dalam menyusun paragraf secara umum yaitu:

1. Gunakan contoh dalam setiap penjelasan konsep abstrak.

2. Gunakan anekdot.

3. Gunakan penggambaran karakter manusia atau setting lokasi jika memang berhubungan.

4. Gunakan skenario untuk menarik pembaca secara langsung seperti bayangan, gambaran atau dugaan.

Lebih lanjut lagi, Sword (2012) memberikan masukan yaitu: pertama, gunakan kata benda kongkrit dan kata kerja yang jelas, terutama ketika membahas konsep abstrak. Kedua, jaga kata kerja dan kata benda sedekat mungkin, sehingga para pembaca dapat dengan menunjukkan siapa menendang siapa?. Ketiga, hindari memperberat kalimat dengan kata-kata dan frasa yang tidak berhubungan.

Berbagai saran tersebut dapat kita gunakan sebagai tambahan pengetahuan dalam menulis paragraf sehingga tulisan kita dapat memiliki variasi yang lebih baik daripada sebelumnya.

\section{Tips Latihan Menulis}

Teknik Freewriting ala Peter Elbow dapat membantu kita untuk melatih kemampuan menulis kita terutama mengoptimalkan pikiran kita agar fokus dan tetap selalu mampu membuat kata yang sesuai dengan topik tulisan. Berikut ini adalah cara menerapakan teknik Freewriting:

1. Gunakan alat tulis seperti pena atau pensil dan medianya seperti kertas, tetapkan tempat yang kemungkinan kamu tidak akan terganggu (tergantung karakter diri bisa tempat ramai atau 
sepi), dan kemudian putuskan untuk menulis sesuatu tanpa ada interupsi dengan waktu tertentu, misalkan 15 menit, 20 menit, 30 menit, 60 menit, dst.

2. Jangan biarkan alat tulis meninggalkan media, biarkan terus menulis secara bebas tanpa mengkoreksi error dan lain-lain. Tujuannya adalah untuk tetap menulis secara berkesinambungan sampai waktu habis

3. Keep writing! sampai waktu habis, hasilnya adalah bukan produk tulisan akan tetapi sebuah proses latihan.

\section{Tips Pilihan Kata}

Kita dapat menggunakan beberapa kata yang lebih kuat makna dan rasa daripada kata-kata yang lebih umum. Artinya mulailah menggunakan kata yang lebih terlihat cool daripada kata yang boring. Berikut ini beberapa contoh kata yang lebih akademis (biasanya merupakan kata serapan) seperti yang penulis dikutip dari Keraf (2004). Untuk berbagai kata lain silahkan lihat di bagian lampiran sebagai bahan kata untuk menulis.
1. Analogi
: Kiasan
2. Anarki
: Kekacauan
3. Bibliografi
: Daftar pustaka
4. Biodata
: Biografi singkat
5. Definisi
: Batasan
6. Diskriminasi
: Perbedaan perlakuan
7. Eksentrik
: Aneh
8. Final
: Akhir
9. Formasi
: Susunan
10. Format
: Ukuran
11. Friksi
: Bagian, Pecahan 
12. Indeks

13. Konklusi

14. Kontemporer

15. Kontradiksi

16. Menganalisa

17. Prediksi

18. Pasien
: Penunjuk

: Kesimpulan

: Masa Kini, Mutakhir

: Pertentangan

: Menguraikan

: Ramalan

: Orang Sakit

Dalam sebuah paragraf tentu tidak semua kata tersebut menjadi kata wajib dalam sebuah paragraf penuh, pembaca akan kesulitan jika terlalu banyak kata akademis atau serapan sehingga bagi penulis urusan menentukan timing dan lokasi yang pas adalah kuncinya. Setidaknya dalam satu paragraf gunakanlah 1 hingga 2 kata tersebut, lebih dari itu pembaca akan kebingungan karena terlalu banyak kata baru yang harus pembaca awam pelajari kecuali dalam tulisan yang sangat akademis yang tentu dipastikan memiliki kata konsep akademis yang sangat banyak sepertidalam jurnal ilmiah.

\section{Tips Menghindari Kekeliruan Logika (Logical Fallacy)}

Dalam menyusun sebuah argumen baik verbal maupun non verbal seperti dalam tulisan kita tentu dilarang untuk mempermainkan logika dasar yang seringkali membawa kepada perdebatan tanpa jalan keluar oleh karena itu kita harus menghindari salah pikir dalam berlogika (logical fallacy).

Menurut Irlanie (2017) setidaknya terdapat tiga jenis cacata logika yaitu: pertama, esalahan logika appeal to authority adalah ketika penulis menganggap sebuah argumen pasti benar karena datang dari institusi/tokoh/figur otoritatif (besar/berkuasa/diakui dunia). Misalkan para anggota dewan berkata bahwa pemerintah dilarang 
untuk memotong subsidi BBM karena akan menyengsarakan rakyat kecil. Argumen tersebut perlu dicek kebenarannya karena subsidi BBM selama ini salah sasaran ke kelas menengah dibandingkan ke rakyat miskin sehingga harus dipotong subsidinya. Kedua, irrelevant conclusion (missing the point). Kesalahan logika ini terjadi ketika argumen tidak menjawab permasalahan/pertanyaan. Misalkan kenapa kita perlu membangun infrastruktur yang memadai? adalah karena untuk mewujudkan Negara yang kompetitif akan tetapi argumen yang tersedia tidak menjawab hal tersebut misalkan malah menuduh Negara adalah antek asing karena terus membangun seperti China atau karena rezim butuh uang korupsi dari pembangunan fisik. Dua argumen tersebut tidak menjawab pertanyaan sebelumnya. Ketiga, after this, therefore because of this. Kesalahan logika ini terjadi ketika kamu mengatakan X yang terjadi setelah Y pasti disebabkan oleh Y. Misalkan kemacetan di Kota-Kota besar Indonesia pasti karena kurangnya pembangunan jalan raya. Argumen tersebut masih perlu dicek karena tidak ada sebab tunggal dalam kemacetan.

Sebenarnya masih terdapat puluhan cacat logika lainnya seperti yang disediakan dalam situs www.yourlogicalfallacyis.com. Dalam kanal tersebut kita akan menemukan 24 jenis cacat logika yang harus kita hindari. Perlu menyisihkan waktu untuk mempelajari cacat logika yang sangat bermanfaat apabila kita menguasainya.

\subsection{Menulis Artikel Utuh}

Menguasai dasar adalah penting sebelum bergerak ke yang lebih rumit. Oleh karena itu pasca memahami dasar menulis kita harus bergerak ke cara menulis dalam potongan-potongan pendahuluan, pembahasan dan penutup yang telah ditetapkan dalam bab inisiasi penulisan artikel. Penulis memilih pendahuluan, pembahasan dan 
penutup sebagai template karena seluruh jenis tulisan murni ilmiah dan ilmiah populer mengandung elemen tersebut meskipun dengan berbagai modifikasi. Berikut ini adalah penjelasan dari masing-masing bagian menulis sebuah artikel yang utuh.

\subsubsection{Menulis Pendahuluan}

Pendahuluan berfungsi untuk mengantarkan pembaca untuk memahami topik dan tujuan tulisan kita. Jadi sebuah pendahuluan harus memasukkan tesis kita yang akan kita giring pembuktiannya dalam bagian pembahasan setelahnya. Sesuai dengan artikel ilmiah populer tentu saja pendahuluan di sini tidak selalu ditulis sebagai pendahuluan dalam sebuah sub bab tersendiri. Kita tidak perlu menuliskannya akan tetapi hanya membuat sebuah paragraf yang berfungsi sebagai pembukaan artikel.

Hal yang paling penting dalam pembukaan adalah kalimat pertama. Setelah melihat sebuah judul maka pembaca akan langsung mengarah pada kalimat pertama dalam tulisan yang akan sangat menentukan apakah tulisan kita dianggap sudah menarik sejak awal sehingga pembaca akan tetap meneruskan proses pembacaan. Kalimatkalimat yang menarik tersebut biasa disebut dengan hook sentence. Oleh karena itu hook sentence dalam paragraf pembuka memang sangat penting oleh karena itu saran berikut ini dapat kita andalkan untuk membuka pendahuluan. Menurut Sword (2012) terdapat 10 cara untuk membuat kalimat pembuka yaitu:

1. Kutipan sastra. Berbagai kalimat pembuka sebuah artikel paling sering menggunakan kutipan dari karya-karya sastra misalkan mengutip dari tulisan Pram "menulis adalah bekerja untuk keabadian" atau Soe Hok Gie "Lebih baik diasingkan daripada 
menyerah pada kemunafikan" atau Soekarno "Jangan sekali-kali melupakan sejarah" atau Sutan Sjahrir "Hidup yang tidak dipertaruhkan tidak akan pernah dimenangkan."

2. Kutipan cendikiawan atau sejarah. Kalimat pembuka juga dapat mengutip kalimat para cendikiawan akan tetapi berbeda dengan kutipan sastra adalah kutipan cendikiawan ini sangat spesifik pada bidang ilmu tertentu misalkan dalam bidang ilmu sosial David Harvey mengatakan "Perampasan adalah bentuk akumulasi kapital" atau Robert Malthus "Laju pertumbuhan penduduk adalah deret ukur, dan laju pertumbuhan pangan adalah deret hitung."

3. Anekdot pribadi. Membuat anekdot adalah salah satu yang paling sulit karena memancing rasa humor akan tetapi tetap berbasis fakta. Misalkan untuk membuat anekdot pribadi kita dapat menceritakan pengalaman pribadi yang lucu kepada pembaca.

4. Sedangkan Anekdot sejarah. Untuk membuat anekdot sejarah kita harus mencari cerita masa lalu yang sesuai dengan topik kita.

5. Anekdot berdasarkan penelitian kita juga dapat dilakukan misalkan ketika dalam proses mengumpulkan bahan atau wawancara kita menemui hal-hal yang aneh, lucu dan tidak terpikirkan sebelumnya.

6. Deskripsi peristiwa. Melalui penggambaran sebuah peristiwa tertentu kita dapat memberikan awal yang menarik bagi pembaca. Peristiwa yang dimaksud juga dapat hanya berupa potongan-potongan kecil misalkan deskripsi lokasi, waktu, orang atau yang lain seperti topik yang sedang kita bahas. 
7. Dialog atau percakapan. Dialog dapat menjadi awal pembuka yang menarik misalkan mengutip dari dialog-dialog karya novel misalkan dalam Max Havelaar atau kita membuat dialog sendiri misalkan percakapan imajiner kita dengan Max Weber ketika membahas sebuah birokrasi.

8. Fakta mengejutkan. Kalimat pembuka dengan jenis ini biasanya membuka dengan fakta-fakta tidak biasa dan aneh. Tentu masih harus berbasis fakta disertai buktinya. Misalkan "Ternyata plagiasi tidak hanya untuk tugas kuliah mahasiswa akan tetapi hingga ke dugaan plagiasi jurnal ilmiah dan bahkan disertasi doktoral" atau "Republik kita setelah 72 tahun merdeka masih tertinggal sangat jauh dari Negara lain bahkan hanya dalam urusan membaca buku."

9. Nasehat langsung kepada para pembaca (pertimbangkan ini, bayangkan itu). Sebuah anjuran untuk pembaca juga dapat menarik minat untuk membaca misalkan dengan kalimat "Mengkritik pemerintah tentu sah-sah saja akan tetapi sebagai warga negara yang baik kita harus tetap objektif dalam melihat kelemahan kebijakan pemerintah" atau "Dalam era informasi serba cepat seperti saat ini, kita tetap wajib memeriksa ulang kebenaran informasi, memastikan validitasnya" atau "Bayangkan jika Negara kita chaos karena konflik berkepanjangan, lebih baik kita saling menjaga persatuan dan kesatuan tanpa membedabedakan."

10. Pertanyaan yang menantang. Kita dapat membuat juga pertanyaan menantang untuk menggugah pembaca untuk ikut serta dalam usaha pencarian jawabannya. Misalkan "Dapatkah kita hidup tanpa pemerintah?" atau "Bisakah internet gratis di Indonesia?" atau "Mungkinkah kita kuliah gratis?" 
Hal yang penting adalah penggunaan kalimat pembuka tersebut harus sesuai dengan maksud dari penggunaannya alias sesuai dengan topik dan tesis kita sendiri. Selain itu juga harus kita ingat selalu bahwa penggunaan kalimat pembuka adalah benar-benar terletak sebagai tulisan pertama kali dalam sebuah tulisan akan tetapi terletak di bawah judul kita.

Menurut pengalaman penulis penggunaan cara di atas sebenarnya dapat digabungkan sesuai dengan kebutuhan. Misalkan tulisan berikut ini:

Kasus DKI Jakarta memang menghasilkan birokrasi berkinerja ala AhokDjarot. Duet ini menghadirkan keberhasilan, meskipun debatable akan tetapi kinerja mereka patut diapresiasi. Namun, itu tidaklah cukup. Sebab, persoalan publik semakin rumit; batas persoalan publik dan privat semakin kabur.

Hadirnya pemimpin baru Jakarta dengan janji politik "partisipasi" AniesSandi dapat membawa tata kelola pemerintahan gaya baru. Tapi, bagaimana dengan implementasinya? Mungkinkah akan terwujud pelayanan publik baru di Jakarta; pelayanan publik yang demokratis yaitu partisipatif, humanis, dan inklusif? (M. Rizki Pratama. 2017, Anies-Sandi dan Harapan Baru Pelayanan Publik. Kolom Detik, 31/05/2017)

Analisis pendahuluan di atas terdiri dari dua paragraf yang paragraf pertama menggunakan deksripsi peristiwa dan paragraf yang kedua menggunakan pertanyaan yang menantang. Oleh karena itu cara-cara tersebut sangat tergantung kita, dapat digabungkan atau digunakan secara tunggal.

\subsubsection{Menulis Pembahasan}

Untuk menepati tesis kita tentu diperlukan berbagai dukungan yang mencukupi oleh karena itu diperlukan sebuah pembahasan yang komprehensif sehingga pembaca juga merasa mendapatkan informasi yang cukup yang menjelaskan tesis kita. 
Dalam artikel ilmiah populer model pembahasan sangat cair tidak seperti pembahasan dalam artikel ilmiah murni yang harus jelas bab dan sub babnya atau dengan urutan tertentu. Beberapa tulisan artikel ilmiah populer biasanya menempatkan judul kecil di atas sebuah paragraf untuk menunjukkan bahwa penulis hendak membahas judul kecil tersebut akan tetapi beberapa tulisan juga tidak mencantumkan judul kecil seperti itu sehingga model penulisan pembahasan benarbenar bebas sesuai dengan selera penulis.

Pembahasan memperlihatkan logika kita dalam menghadapi suatu permasalahan, mencoba untuk menyelesaikannya dan memberikannya kepada pembaca atau mengkomunikasikan kepada pembaca. Untuk mengkomunikasikan informasi yang saling berhubungan dapat digunakan empat pola penjelasan (eksplanasi) oleh Patrick Dunleavy (2003), yaitu:

1. Penjelasan deskriptif: penggambaran dunia nyata, apa adanya. Misalkan kita menulis tentang kebijakan maritim pada era Menteri Susi Pudjiastuti maka dengan penjelasan deskriptif pada pembahasan kita dilarang membuat sesuatu berdasarkan klaim kita tetapi hanya menggambarkan sesuatu yang sudah ada pada kebijakan Bu Susi seperti penenggelaman kapal maling ikan dan pelarangan penggunaan cantrang.

2. Penjelasan analitik: kita yang membentuk kategorisasi, klasifikasi, bukan berdasarkan dunia nyata akan tetapi dari pemikiran kita. Sedangkan dengan cara analisis jika kita tetap membahas kebijakan maritim pada era Menteri Susi Pudjiastuti maka kita harus membuat kategorisasi atau klasifikasi berdasarkan pemikiran kita yang mengandalkan kemampuan konseptual kita seperti membaginya menjadi efektivitas 
kebijakan maritim era Susi Pudjiastuti, dampak langsung kebijakan maritim bagi nelayan kecil, dan Susi Pudjiastuti membasmi kemiskinan lewat laut.

3. Penjelasan argumentatif: kita membentuk pro atau kontra pada suatu pembahasan. Masih dengan topik yang sama kita dapat membuat berbagai macam keberpihakan pada tulisan kita dengan cara argumentatif seperti jika kita pro dengan kebijakan maritim di era Susi Pudjiastuti kita harus menunjukkan berbagai manfaat dan keunggulannya sedangkan ketika dalam posisi kontra kita jelas menunjukkan kerugian dan kelemahannya.

4. Pola metrik: bisa juga pola yang tidak tunggal, kombinasi dari dua penjelasan. Kita dapat menggunakan dua pola sekaligus dalam pembahasan misalkan dengan kombinasi penjelasan deksriptif dan analitik dengan topik yang sama kita dapat menggunakannya dengan langkah berikut yaitu kita gunakan deskripsi dahulu baru kemudian menganalisisnya ataupun sebaliknya. Ketika deskripsi dahulu maka hasilnya adalah penenggelaman kapal maling ikan dan pelarangan penggunaan cantrang lalu baru kita analisis kemudian masing-masing misalkan pada penenggalaman kapal ikan kita bagi menjadi efektivitas dan kerugian penenggalaman kapal ikan sedangkan pada pelarangan penggunaan cantrang kita bagi menjadi dampaknya bagi nelayan kecil dan metode pengawasan pelarangan. Kita juga masih dapat menggabungkan beberapa penjelasan yang lainnya. 
Misalkan berikut ini adalah contoh penggunaan penjelasan deskriptif yaitu dengan kalimat topik ketimpangan pelayanan publik yang merinci ketimpangan di dunia pendidikan dasar hingga perguruan tinggi.

Sektor-sektor pelayanan publik strategis seperti pendidikan dan kesehatan menggambarkan secara sosial ketimpangan pelayanan publik. Tiap tahun dapat kita lihat perilaku orang tua murid kebingungan mencari sekolah yang dianggap "terbaik" bagi putra-putrinya karena tidak ada jaminan mendapatkan kualitas pendidikan yang sama jika bersekolah di tempat lain, antar Sekolah Dasar (SD) Negeri pun bersaing dengan mewajibkan siswa baru di kelas 1 sudah wajib menguasai baca tulis hitung (calistung), bahkan di Sekolah Menengah Atas (SMA) berani promosi bahwa siswa-siswinya berhasil lulus UN 100\% bahkan juga memampang prestasi alumninya yang berhasil menembus perguruan tinggi terbaik fatalnya keberhasilan tersebut pasti ditunjang oleh privatisasi pembelajaran oleh lembaga belajar yang justru menjadi tumpuan siswa mampu untuk mencapai prestasi daripada di sekolah. Di level pendidikan tinggi juga mengalami hal yang mirip. Biaya pendidikan semakin tinggi dan lapangan pekerjaan yang semakin sempit, tambahan lain bahwa banyak diantara pelajar yang salah jurusan ketika memilih program studi padahal total para pelajar yang mampu mengenyam pendidikan hingga perguruan tinggi tidak lebih dari 10\%. (M. Rizki Pratama. 2017, Ketimpangan Pelayanan Publik, Opini Harian Republika 13/03/2017)

Khusus untuk cara pembahasan dengan analisis para penulis perlu mempertimbangkan nuansa dari analisa sendiri yaitu:

1. Analisa historis. Analisis ini merupakan hal yang sering hilang oleh seorang penulis pemula bahkan beberapa penulis dalam sebuah koran lokal sering penulis tandai karena lupa menjelaskan darimana asal-usul konsep yang digunakan. Analisis historis atau sejarah ini penting untuk menunjukkan asal usul hal-hal yang kita bahas, jangan sampai anda menuliskan ide anda ternyata sudah ada penulis lain yang jauhjauh hari menuliskan hal tersebut. Tulisan anda menjadi usang, selain itu analisis historis ini juga dapat menunjukkan klaim pengetahuan anda pada masalah tertentu yaitu dengan 
mengetahui apa yang sudah terjadi di masa lalu bukan asal menulis yang anda pikir ide orisinil anda akan tetapi secara tidak sadar anda mendapatkan ide tersebut dari sumber-sumber lain yang anda lupa atau lupakan. Misalnya ketika menulis tentang pemberdayaan masyarakat perlu bagi kita untuk menjelaskan sejarah singkatnya dalam beberapa kata.

2. Analisa kontekstual. Analisis ini mencoba untuk mengkaitkan konsep-konsep yang sekiranya cukup sulit untuk dipahami oleh pembaca awam. Anda harus mencoba mendefiniskannya terlebih dahulu dan kemudian mengkaitkannya dengan konteks Indonesia ataupun konteks lokalitas di daerah anda. Misalnya mengenai konsep politik yang biasa cukup sulit dipahami oleh masyarakat awam kita perlu mendefinisikannya dan disertai contoh yang sesuai dengan kondisi di mana pembaca kita tinggal.

3. Analisa kepakaran. Sebagai seorang penulis yang tentu saja bacaan harus lebih banyak daripada tulisan sangat perlu untuk mengetahui siapa pakar-pakar ataupun tokoh dalam topik yang anda tulis. Jangan sampai tulisan anda sama sekali tidak mencantumkan para pakar tentang topik yang sedang anda bahas karena anda memang tidak membaca karya-karya awal tentang topik yang anda tulisan. Hal ini dapat membuat pembaca meragukan tulisan anda. Misalkan anda tengah menulis tentang topik inovasi maka buku-buku dari Rhenald Khasali perlu untuk menjadi bahan analisis.

4. Analisa kritis. Analisis ini merupakan analisis yang paling sulit sebab anda harus benar-benar menguasai topik yang anda tulis. Tidak hanya membaca satu dua artikel ataupun buku akan tetapi benar-benar mengatahui kabar terkini topik tersebut, 
kelemahan, keunggulan suatu topiik, dan saran anda untuk memperbaiki kelemahan tersebut. Analisis dipastikan menggunakan logika terbalik atau anti arus utama misalkan anda menulis tentang kebijakan infrastruktur di Indonesia maka analisis anda harus membalik logika kebijakan infrastruktur di Indonesia yang secara umum dinilai bermanfaat menjadi sama sekali tidak bermanfaat karena menimbulkan konflik masyarakat adat, kerusakan lingkungan dan ketidakmerataan pembangunan.

\subsection{Menulis Penutup}

Dua hal penting dalam sebuah penutup dalam tulisan ilmiah populer adalah: Pertama mempertahankan tesis. Hal terakhir yang harus kita lakukan dalam menyudahi tulisan kita adalah memberikan pandangan terakhir kita pada tesis yang sudah kita ajukan. Pada dasarnya kita harus mempertahankan tesis kita sejak awal karena dengan tesis yang tetap bertahan maka ide kita memang benar-benar sesuai dengan pembahasan sebelumnya. Kedua, derajat call for action. sedikit berbeda dengan penutup pada tulisan ilmiah murni, biasanya tulisan ilmiah populer lebih memberikan saran dan harapan terhadap suatu permasalahan. Tentu sangat berbeda dengan karya ilmiah populer yang menuntut terpenuhinya aspek metodologi dalam menuju kesimpulan, limitasi studi dan penelitian selanjutnya. 
Berikut ini adalah contoh menutup sebuah artikel ilmiah populer yaitu mempertahankan tesis berupa kewajiban Negara menyelenggarakan pelayanan publik dan saran bagi seluruh pihak untuk ikut serta dalam memperbaiki pelayanan publik.

Akhir kata, memang tak serta-merta negara dapat memenuhi seluruh kebutuhan dasar masyarakat. Perlu kerja sama kita semua untuk ikut belajar memahami hak dan kewajiban kita, termasuk ikut serta dalam upaya memperbaiki pelayanan publik di sekitar kita......Semoga pesan ini menjadi pertimbangan pemimpin baru Republik ini karena kita memiliki rakyat yang keberlanjutan hidupnya harus dilindungi melalui public service. (M. Rizki Pratama. 2014, Pertumbuhan Ekonomi dan Pelayanan Publik, Opini Harian Kompas 07/08/2014)

Selain itu contoh di bawah ini juga mempertahankan tesis bahwa Negara harus menggunakan logika pelayanan publik dan menyarankan penggunaannya untuk masyarakat.

Optimistik memang perlu dikedepankan, jelas republik ini punya potensi tetapi sekali lagi logika pembangunan yang digunakan harus tepat jangan melenceng dari logika pelayanan publik yang seharusnya ada untuk masyarakat. (M. Rizki Pratama. 2016, Logika Pelayanan Publik, Opini Harian Jawa Pos (09/01/2016) 


\section{BAB IV}

\section{EVALUASI PENULISAN ARTIKEL}

Sebagai sebuah produk yang memiliki hasil akhir tentu diperlukan pemeriksaan kualitas akhir (quality control) untuk memenuhi standarstandar tertentu. Seperti telah dituliskan sebelumnya bahwa lebih baik kita menulis terlebih dahulu hingga selesai daripada langsung melakukan revisi terus-menerus bersamaan dengan proses penulisan sendiri. Beberapa langkah penting yang harus dilakukan agar tulisan kita memiliki kualitas yang kita harapkan antara lain:

\subsection{Revisi Tulisan}

Revisi tulisan sendiri terdiri dari 3C yaitu: pertama, cek tata bahasa, kedua, cek kesatuan, koherensi dan pengembangan, ketiga, cek sumber.

Pertama, Untuk melakukan cek tata bahasa tentu pertama kali kita harus melihat kesalahan ejaan dalam tulisan kita. Sebagai penulis yang baik sangat dianjurkan untuk tidak memiliki kesalahan sedikit pun pada ejaan tulisan alias typo seluruh kata harus ditulis sesuai dengan ketentuannya karena hal tersebut sudah merupakan kewajiban yang tidak dapat dipermasalahkan kembali.

Untuk tata bahasa yang lain seperti kata depan, penulis menganjurkan untuk sering mengunjungi kanal milik Badan Bahasa Indonesia dan website pribadi Ivan Lanin. Keduanya sering menunjukkan posting berbagai kesalahan kita dalam berbahasa Indonesia yang baik dan benar. Selain via website mereka juga memiliki akun twitter. Silahkan google dan follow twitter mereka. 
Kedua, untuk cek yang kedua merupakan langkah yang kritikal karena menentukan kualitas esensial tulisan, apakah tulisan kita terlihat menyatu, tidak ada transisi yang menyulitkan pembaca, informasi yang disajikan cukup jelas dan apakah penutup sudah sesuai dengan apa yang kita harapkan.

Ketiga untuk melakukan cek sumber harus dilakukan untuk mengecek referensi yang digunakan dan juga sumber data jangan sampai salah melakukan kutipan ataupun menggunakan sumber yang tidak relevan, dan bahkan sumber data yang tidak jelas kredibilitasnya selain itu juga update referensi dan data harus kita ikuti dengan baik jangan sampai kita berusaha menulis opini kontemporer akan tetapi data dan sumber kita ternyata sudah ketinggalan zaman.

\subsection{Mencari Umpan Balik}

Pencarian umpan balik adalah salah satu kelemahan kita dalam membuat tulisan sebab sering sekali bagi kita menganggap tulisan kita sudah yang paling sempurna dan langsung menggunakannya untuk tujuan tertentu padahal tentu masih ada peluang untuk mempertajam tulisan kita dengan sedikit usaha lagi oleh karena sempatkanlah untuk mencari umpan balik misalkan dengan berdiskusi dengan rekan-rekan anda atau siapa saja yang anda perkirakan memiliki kemampuan untuk memberikan pendapat pada tulisan anda. Bundel ini juga merupakan hasil review dari beberapa rekan penulis.

Misalnya dalam pengerjaan karya-karya ilmiah buku ataupun jurnal ilmiah, banyak penulis utama memberikan ucapa terima kasih secara tertulis pada berbagai pihak atas masukan yang telah diterima. Hal tersebut membuktikan bahwa umpan balik sangat penting, selain itu misalkan dalam pengerjaan paper-paper tugas kuliah ataupun karya 
ilmiah seperti skripsi/tesis, sangat terlarang bagi mahasiswa untuk mengerjakan secara diam-diam dan jika selesai pasti akan terkejut dengan hasilnya, bukannya bagus akan tetapi dibantai dalam forum. Oleh karena kita dapat membuat atau menemukan komunitas yang sesuai dengan kepentingan kita untuk mendapatkan umpan balik.

\subsection{Mengirimkan Tulisan}

Mengirimkan tulisan termasuk dalam tahapan yang sifatnya evaluatif karena pada dasarnya ketika tulisan kita dirasa sudah selesai dan kemudian kita mengirimkannya ke media tertentu maka kita sendiri akan mendapatkan penilaian atass tulisan kita sendiri baik personal ataupun dari media tersebut.

Secara personal ketika mengirimkan sebuah tulisan maka sebenarnya kita sudah menilai tulisan kita sendiri cukup layak untuk dikirimkan sehingga dari usaha evaluasi personal. Bahkan ketika kita membaca ulang lagi naskah tulisan kita seringkali akan muncul ide-ide lain yang dapat digunakan untuk menulis tulisan lain. Itulah yang disebut menulis sebagai proses yang menuntut kita untuk tidak berhenti di tempat, selalu terus menerus belajar kembali menemukan hal-hal baru.

Media tempat kita mengirimkan naskah juga dapat memberikan evaluasi misalkan media yang rajin memberikan masukan adalah kompas melalui redaksi opini mereka sebab naskah kita akan mereka baca untuk menentukan layak terbit atau tidak. Ketika tidak layak terbit maka redaksi akan mengirimkan email resmi yang berisi permohonan maaf bahwa tulisan kita tidak dapat diterbitkan dengan berbagai alasan seperti tulisan di luar kompetensi penulis, tulisan bukan merupakan hal baru dan lain-lain. Redaksi Kompas juga tetap memberikan saran 
kepada kita agar tetap terus mengirimkan naskah kepada mereka. Evaluasi dari redaksi Kompas dapat menjadi masukan berharga bagi kita sebab memberikan alasan yang relevan ketika tulisan kita tidak dapat mereka terbitkan. Selain kompas. Geotimes juga tidak dapat secara langsung menerbitkan tulisan kita meskipun kita pribadi yang meng-upload tulisan kita ke kanal Geotimes akan tetapi mereka akan tetap melakukan review terhadap tulisan kita sebelum benar-benar diterbitkan secara online. Untuk alamat redaksi media lain silahkan anda cek di bagian lampiran akhir dalam bundel ini. 


\section{BAB V}

\section{CATATAN AKHIR}

Berbagai tulisan dalam bundel ini bukanlah sebuah rumus paten, anda harus menemukan gaya tulisan anda sendiri, segala panduan langkah-langkah dalam bundel hanya merupakan penambahan akumulasi pengetahuan menulis kita. Bukan menjustifikasi bahwa tulisan-tulisan anda sebelum membaca bundel ini adalah nol besar, akan tetapi setelah membaca bundel ini anda dapat mengembangkan dan memperbaiki tulisan anda menjadi lebih baik. Memang, tugas besar kita adalah menyatukan seluruh pengetahuan yang kita miliki untuk berkarya dalam sebuah tulisan.

Tulisan yang berkualitas adalah yang benar-benar anda tulis sendiri, dengan karakter gaya anda sendiri. Para penulis harus menemukan dirinya sendiri lewat tulisan mereka yang dibentuk lewat pengalaman dan pengujian yang panjang dan melelahkan.

Setiap paragraf tulisan harus kita nikmati sebagai curahan pemikiran mendalam kita bukan sebuah penderitaan menyakitkan, memang para penulis profesional akan mengalami tekanan luar biasa bahkan para mahasiswa tingkat doktoral pun masih mengalami stuck dalam menulis karya ilmiah mereka sendiri maka sebagai pemula kita pun dilarang mengeluh. Kepuasan ketika menyelesaikan tulisan merupakan penghapus lelah bahkan nilai yang kita dapatkan tidak akan sebanding dengan nilai material dari tulisan kita. Semoga sukses dengan tulisan kita, mari kita bersama-sama belajar menulis dengan baik dan benar. 


\section{REFERENSI}

Cardiff Metropolitan University. 2016, Writing Techniques:

Constructing a Paragraph, Academic Skill Specialist. Cardiff.

(diakses dari www.study.cardiffmet.ac.uk).

Cheeney, Theodore A. Ress. 2001, Writing Creative Nonfiction Fiction Techniques for Crafting Great Nonfiction. Ten Speed Press:

California.

Creswell, John W. 2010, Research Design: Pendekatan Kualitatif, Kuantitatif, dan Mixed. Pustaka Pelajar: Yogyakarta.

Dunleavy, Patrick. 2003, Authoring PHD: How to Plan, Draft, and Finish a Doctoral Thesis or Dissertation. Palgrave McMillan: New York.

Geertz, Clifford. 1973, The Interpretation of Culture. Basic Books: New York.

Irlanie, Cania Citta. 2017, Tips Menulis. (diakses dari http://cittairlanie.com/2017/07/16/tips-menulis/).

Keraf, Gorys. 2004, Diksi dan Gaya Bahasa. Jakarta: Gramedia Pustaka Utama. (diakses dari

http://pelitaku.sabda.org/menulis artikel ilmiah populer).

Lele, Gabriel, et al. 2010, Panduan Penulisan Akademik. FISIPOL UGM: Yogyakarta.

Lewis, Oscar. 1969. A Death in the Sanchez Family. Penguin Books: Victoria.

Lund, Christian. 2014, Of What is This a Case?: Analytical Movements Qualitative Social Science Research. Human Organization. Vol. 73 (3).

Meier, Kenneth J., Jeffrey L. Brudney \& John Bohte. 2012, Applied Statistics for Public and Non-Profit Administration. Wadsworth Cengage Learning: Boston.

Patton, Michael Quinn. 2009, Metode Evaluasi Kualitatif. Pustaka Pelajar: Yogyakarta.

Popper, Karl. 2002, The Logic of Scientific Discovery. Routlegde: London.

Pratama, M. Rizki. 2016, Logika Pelayanan Publik, Opini Harian Jawa Pos $(09 / 01 / 2016)$ 
Pratama, M. Rizki. 2017, Anies-Sandi dan Harapan Baru Pelayanan Publik. Kolom Detik (31/05/2017).

Pratama, M. Rizki. 2017, Ketimpangan Pelayanan Publik, Opini Harian Republika (13/03/2017).

Silvia, Paula J. 2007, How to Write a Lot: A Practical Guide to Productive Academic Writing. American Psychological Association: Washington D.C.

Sword, Helen. 2012, Stylish Academic Writing. Harvard University Press: Cambridge.

Tanjung, Bahdin Nur \& Ardial. 2009, Pedoman Penulisan Karya Ilmiah (Proposal, Skripsi dan Tesis): dan Mempersiapkan Diri Menjadi Penulis Artikel Ilmiah. Kencana: Jakarta.

Uco, Umberto. 2015, How to Write a Thesis. MIT Press: Cambridge.

Whitaker, Anne. 2010, Academic Writing Guide: A Step-by-Step Guide to Writing Academic Papers. City University of Seattle: Seattle. (diakses dari www.vsm.sk/Curriculum/academicsupport/academicwritingguid e/pdf).

Whitehead, Toni L., 2005. Basic Classical Ethnographic Research Methods: Secondary Data Analysis, Fieldwork, Observation/Participation Observation and Informal and Semistructured Interviewing. Department of Anthropology University of Maryland: Maryland.

Zinsser, William. 2005, On Writing Well: The Classic Guide to Writing Nonfiction. HarperCollins: New York.

Nordquist, Richard. 2017, Development (composition): Glossary of Grammatical and Rhetorical Terms. (diakses dari www.thoughtco.com/development-composition-term16903830). 


\section{LAMPIRAN}

\section{Kamus Kata Umum dan Ilmiah}

\begin{tabular}{|c|c|c|}
\hline No. & Kata Umum & Kata Ilmiah \\
\hline 1. & Kesenjangan/Ketimpangan & Disparitas \\
\hline 2. & Penghapusan & Abolisi \\
\hline 3. & Munafik & Hipokrit \\
\hline 4. & Masa kini & Kontemporer \\
\hline 5. & Penafsiran & Interpretasi \\
\hline 6. & Tindakan & Aksi \\
\hline 7. & Main Hakim Sendiri & Persekusi \\
\hline 8. & Anggapan sebelum mengetahui & Apriori \\
\hline 9. & Penyertaan & Inklusi \\
\hline 10. & Tidak seimbang & Asimetris \\
\hline 11. & Cerita & Narasi \\
\hline 12. & Ambil alih & Pembajakan \\
\hline 13. & Ketunaan & Disabilitas/Difabel \\
\hline 14. & Kurang & Minus \\
\hline 15. & Lebih & Plus \\
\hline 16. & Penghancuran & Destruksi \\
\hline 17. & Pembuatan & Konstruksi \\
\hline 18. & Kecil & Minimal \\
\hline 19. & Membuat ulang & Rekonstruksi \\
\hline 20. & Pemisahan & Separasi \\
\hline 21. & Wacana Ilmiah & Diskursus \\
\hline 22. & Pendapat & Opini \\
\hline 23. & Nalar & Logika \\
\hline 24. & Kolot & Konservatif \\
\hline
\end{tabular}




\begin{tabular}{|c|l|l|}
\hline 25. & Bermakna Ganda & Ambigu \\
\hline 26. & Penguraian & Analisis \\
\hline 27. & Cara & Metode \\
\hline 28. & Umum ke Khusus & Deduktif \\
\hline 29. & Khusus ke Umum & Induktif \\
\hline 30. & TIdak Nyata & Semu \\
\hline 31. & Perkiraan & Proyeksi \\
\hline 32. & Jalur Perkiraan & Trajektori \\
\hline 33. & Calon Pejabat yang Masih Menjabat & Petahana \\
\hline 34. & Pemilihan Anggota Baru & Kooptasi \\
\hline 35. & Penyelesaian Kembali & Resolusi \\
\hline 36. & Perubahan Drastis & Reformasi \\
\hline 37. & Pengurangan & Reduksi \\
\hline 38. & Perluasan & Ekspansi \\
\hline 39. & Luar Biasa Banyak & Masif \\
\hline 40. & Pembuatan & Produksi \\
\hline 41. & Modal & Kapital \\
\hline 42. & Individu/Pribadi/Swasta & Privat \\
\hline 43. & Kinerja & Performa \\
\hline 44. & Tidak Jelas & Blur \\
\hline 45. & Berkemanusiaan & Humanis \\
\hline 46. & Penilaian & Justifikasi \\
\hline 47. & Faktor Penting & Determinan \\
\hline 48. & Perselisihan & Konflik \\
\hline 49. & Kompak & Solid \\
\hline 50. & Pokok Ajaran Tanpa Bantahan & Dogma \\
\hline 51. & Mangkus & Efektfif \\
\hline 52. & Sangkil & Efisien \\
\hline
\end{tabular}




\begin{tabular}{|c|l|l|}
\hline 53. & Kasih Penulisng & Afeksi \\
\hline 54. & Penguasaan & Dominasi \\
\hline 55. & Pernyataan Dugaan & Tesis \\
\hline 56. & Membalik Tesis & Anti tesis \\
\hline 57. & Keterwakilan & Representasi \\
\hline 58. & Waktu & Era \\
\hline 59. & Budaya & Kultur \\
\hline 60. & Keuangan & Fiskal \\
\hline 61. & Cela & Kritik \\
\hline 62. & Ambruk & Tumbang \\
\hline 63. & Golongan Kecil & Minoritas \\
\hline 64. & Golongan Bsar & Mayoritas \\
\hline 65. & Sebagian & Parsial \\
\hline 66. & Penetapan Positif & Afirmasi \\
\hline 67. & Penegasan & Konfirmasi \\
\hline 68. & Calo & Komprador \\
\hline 69. & Rinci & Detil \\
\hline 70. & Masalah & Problem \\
\hline 71. & Penilaian & Evaluasi \\
\hline 72. & Yang Diutamakan & Prioritas \\
\hline 73. & Penerapan & Implementasi \\
\hline 74. & Pemburu & Predator \\
\hline 75. & Faktor yang Dapat Berubah & Variabel \\
\hline 76. & Campur Tangan & Intervensi \\
\hline 77. & Penyembuhan & Kuratif \\
\hline 78. & Persaingan & Kompetisi \\
\hline 79. & Urutan tingkatan & \\
\hline 80. & Organisasi Hierarki & \\
\hline & & Hirokrasi \\
\hline
\end{tabular}




\begin{tabular}{|r|l|l|}
\hline 81. & Tidak Nyata & Imajiner \\
\hline 82. & Gambaran Rinci & Deskripsi \\
\hline 83. & Pencarian/Penggalian/Pendalaman & Eksplorasi \\
\hline 84. & Perbaikan & Restorasi \\
\hline 85. & Pemesanan & Reservasi \\
\hline 86. & Penyederhanaan & Simplifikasi \\
\hline 87. & Perubahan Mendasar & Revolusi \\
\hline 88. & Pengaruh & Konsekuensi \\
\hline 89. & Pembatasan & Restriksi \\
\hline 90. & Resmi & Formal \\
\hline 91. & Kemampuan Adaptasi & Resiliensi \\
\hline 92. & Khayalan & Delusi \\
\hline 93. & Pengalihan Perhatian & Distraksi \\
\hline 94. & Harapan & Ekspetasi \\
\hline 95. & Kemunduran & Resesi \\
\hline 96. & Lengkap & Komprehensif \\
\hline 97. & Dapat dipercaya & Bernas \\
\hline 98. & Perlindungan & Proteksi \\
\hline 99. & Pendapat & Argumen \\
\hline 100. & Jarak & Gap \\
\hline 101. & Maksud/Tujuan & Intensi \\
\hline 102. & Perhatian & Atensi \\
\hline 103. & Memperluas & Ekstensif \\
\hline 104. & Berangsur-angsur & Gradual \\
\hline 105. & Kadang Kala & Respek \\
\hline 106. & Hormat & Rompensasi \\
\hline 107. & Terlalu dini & \\
\hline 108. & Ganti Rugi & \\
\hline
\end{tabular}




\begin{tabular}{|c|c|c|}
\hline 109. & Penggalan & Fragment \\
\hline 110. & Proses Mundur & Regresi \\
\hline 111. & Penculikan & Abduksi \\
\hline 112. & Peremajaan & Regenerasi \\
\hline 113. & Hubungan & Korelasi \\
\hline 114. & Hubungan & Relasi \\
\hline 115. & Penggandaan & Replikasi \\
\hline 116. & Penyebaran & Difusi \\
\hline 117. & Sebab akibat & Kausal \\
\hline 118. & Garis Keturunan & Genealogi \\
\hline 119. & Ampas & Residu \\
\hline 120. & Pembalikan & Inversi \\
\hline 121. & Perbaikan & Reparasi \\
\hline 122. & Dugaan Sementara & Hipotesis \\
\hline 123. & Memusat & Konvergensi \\
\hline 124. & Penyebaran & Divergensi \\
\hline 125. & Lembaga & Intitusi \\
\hline 126. & Kesepakatan Bersama & Konsensus \\
\hline 127. & Memiliki Nama Baik & Reputasi \\
\hline 128. & Tambahan & Bonus \\
\hline 129. & Tambahan & Insentif \\
\hline 130. & Bagian Kecil & Fraksi \\
\hline 131. & Cerminan & Refleksi \\
\hline 132. & Penyebaran & Diseminasi \\
\hline 133. & Pengertian & Definisi \\
\hline 134. & Kumpulan & Kompilasi \\
\hline 135. & Kaum Pinggiran & Marjinal \\
\hline 136. & Pemurnian & Refinasi \\
\hline
\end{tabular}




\begin{tabular}{|c|l|l|}
\hline 137. & Ajeg & Konsisten \\
\hline 138. & Terpercaya & Reliabel \\
\hline 139. & Persilangan & Hibrid \\
\hline 140. & Sahih & Valid \\
\hline 141. & Kesamaan status & Ekualitas \\
\hline 142. & Awalan & Inisiasi \\
\hline 143. & Prakarsa & Inisiatif \\
\hline 144. & Pokok & Substansi \\
\hline 145. & Kenyataan & Empiris \\
\hline 146. & Penyimpulan Umum & Generalisasi \\
\hline 147. & Kaidah & Normatif \\
\hline 148. & Kenyataan & Realitas \\
\hline 149. & Ancaman & Intimidasi \\
\hline 150. & Berporos sama & Koaksial \\
\hline 151. & Penggandaan & Duplikasi \\
\hline 152. & Swasta & Partikelir \\
\hline 153. & Izin & Konsesi \\
\hline 154. & Kekacauan & Anarki \\
\hline 155. & Rasa Benci & Antipati \\
\hline 156. & Perhitungan Ke Depan & Antisipasi \\
\hline 157. & Daftar Pustaka & Bibliografi/Referemsi \\
\hline 158. & Kemunduran & Depresi \\
\hline 159. & Bentuk,Wujud & Figur \\
\hline 160. & Cabang & Filial \\
\hline 161. & Penyaringan & Harmonis \\
\hline 162. & Rasa Kecewa & Indeks \\
\hline 163. & Sesuai & \\
\hline 164. & Penunjuk & \\
\hline
\end{tabular}




\begin{tabular}{|c|l|l|}
\hline 165. & Keterangan & Informasi \\
\hline 166. & Pendahuluan & Introduksi \\
\hline 167. & Penyerahan & Kapitulasi \\
\hline 168. & Ringkasan & Sinopsis \\
\hline 169. & Sifat cemburu & Posesif \\
\hline 170. & Perwujudan & Realisasi \\
\hline 171. & Tidak Normal & Abnormal \\
\hline 172. & Petempur & Kombatan \\
\hline 173. & Penjahat kambuhan & Residivis \\
\hline 174. & Keras Menuntut Perubahan & Radikal \\
\hline 175. & Secara Terbuka & Frontal \\
\hline
\end{tabular}

Sumber: Dikompilasi dari Kamus KBBI Edisi V, Eneste (1995) dalam

Tanjung \& Ardial (2005) \& Pengalaman Pribadi Penulis

\section{Alamat Redaksi Media untuk Artikel}

- Jawa Pos (opini@jawapos.co.id). Honor sekitar Rp. 800 ribu. Tidak ada pemberitahuan pemuatan artikel, penulis harus mengkonfirmasi pemuatan kepada redaksi untuk pencairan honor.

- Republika (sekretariat@republika.co.id). Honor sekitar Rp. 750 ribu, tidak ada pemberitahuan pemuatan artikel, harus sabar menagih ke redaksi, pengalaman penulis honor baru cair 2 bulan pasca penerbitan.

- Kompas (opini@kompas.com). Salah satu media dengan opini kelas berat. Honor sekitar Rp. 900 ribu, anda akan dihubungi oleh redaksi ketika tulisan anda akan dimuat, beserta copy digital tulisan anda, honor cair 2 minggu pasca penerbitan. Pengalaman penulis redaksi kompas sangat responsif dalam menghubungi penulis. 
- Detik (redaksi@detik.com). Honor Rp. 500 ribu, tidak ada pemberitahuan pemuatan artikel. Redaksi cukup responsif dalam honor yang ditransfer 2 minggu pasca pemuatan.

- Koran Sindo (redaksi.sindonews@mncgroup.com). Sindo memiliki kanal khusus yang memuat opini para mahasiswa. Honor sekitar Rp. 500 ribu. Masing-masing terbitan memiliki tema tersendiri sehingga kita harus menyesuaikan dengan tema tersebut.

- Koran Tempo (koran@tempo.co.id). Salah satu media yang menyediakan opini kelas berat akan tetapi tidak ada salahnya kita mengirim tulisan kita.

- Bisnis Indonesia (sekred@bisnis.com). Opini hanya memuat tulisan tentang bisnis dan ekonomi.

- Geotimes. (redaksi@geotimes.co,id). Sebagai latihan menulis anda dapat menggunakan media Geotimes. Silahkan mendaftar secara online untuk menulis opini di Geotimes, anda dapat menyebarkan tulisan anda sekaligus mengetahui jumlah viewer tulisan anda.

- Kedaulatan Rakyat (KR) Jogja (redaksi@krjogja.com). Koran lokal di Yogyakarta yang hanya menerima tulisan isu-isu lokal di Yogyakarta. Honor sekitar 300 ribu.

- Tribbunnews (redaksi@tribunnews.com). Masing-masing daerah terbitan memiliki kolom opini tersendiri, cukup bagus untuk melatih tulisan kita.

- Suara Pembaruan (koransp@suarapembaruan.com). Kanal ini masih satu grup dengan berita satu, menerima berbagai macam jenis opini.

- Kumparan (redaksi@kumparan.com). Sebagai latihan menulis anda dapat menggunakan media Kumparan. Silahkan mendaftar secara online untuk menulis opini di Kumparan, anda dapat menyebarkan tulisan anda sekaligus mengetahui jumlah viewer tulisan anda. 
